\title{
HAZARD TREE MANAGEMENT PLAN
}

\author{
Glacier National Park \\ West Glacier \\ Montana, 59936
}

March 1994

\section{STATE DOCUMEIITS COLLËTIOVi}

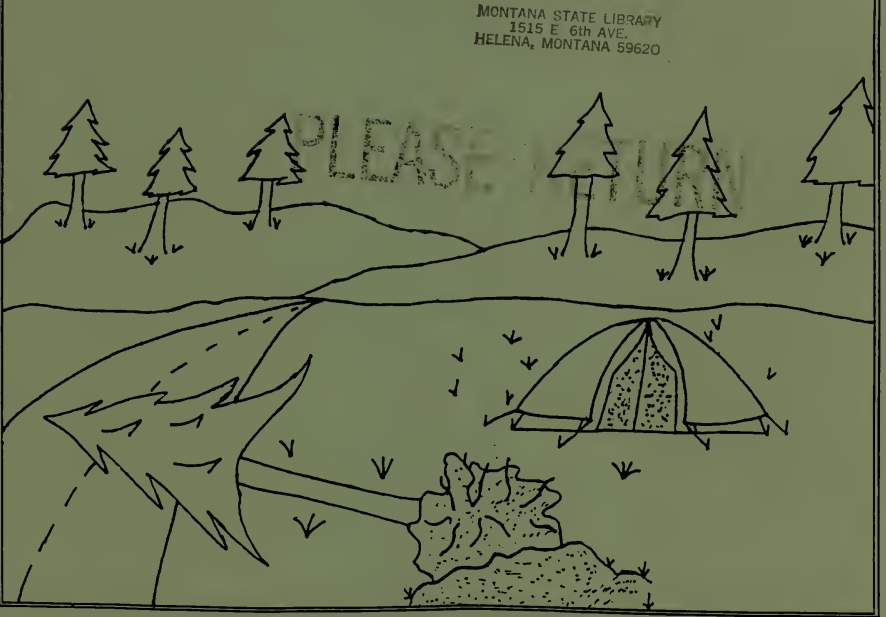




\title{
HAZARD TREE MANAGEMENT PLAN
}

\author{
Glacier National Park \\ West Glacier \\ Montana \\ 59936
}

March 1994

Prepared and Reviewed by the Resources Management Division

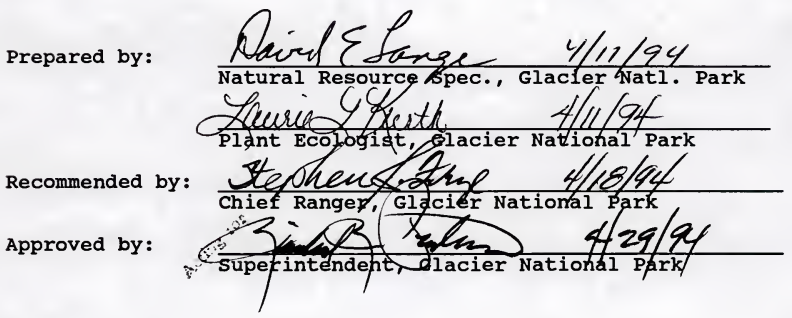


(2)

○

○

○

0

0

-

-

? 


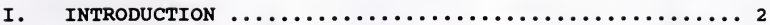

II. AUTHORIZATION $\ldots \ldots \ldots \ldots \ldots \ldots \ldots \ldots \ldots \ldots \ldots \ldots \ldots \ldots \ldots \ldots \ldots$

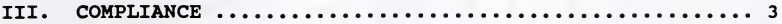

IV. PROCEDURES FOR OPERATIONS $\ldots \ldots \ldots \ldots \ldots \ldots \ldots \ldots \ldots \ldots$

A. Annual Work plan.....................4

B. Survey to Identify Hazard Trees............. 5

C. Select Mitigation Action.................. 9

D. Implement Mitigation Action.................11

E. Document Work.........................11

v. SITE REHABILITATION AND/OR MONITORING...........12

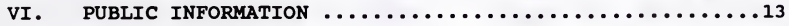

viI. ROLES AND RESPONSIBILITIES $\ldots \ldots \ldots \ldots \ldots \ldots \ldots \ldots \ldots \ldots$

A. Resources Management Division.............13

B. Maintenance Division.....................

C. Interpretation Division....................

D. Lands, Safety, Concessions Division.........14

E. Training........................

APPENDICES
A. DEFINITIONS
B. HAZARD TREE MANAGEMENT DECISION TREE
C. TREE RATING CRITERIA AND EXAMINATION PROCESS
D. PROBABILITY THAT A TREE WILL HIT A TARGET
E. HAZARD TREE SURVEY FIELD RECORD FORM
F. COMMON HAZARDS OF PARK TREE SPECIES
G. LITERATURE CITED 
0

-



○

-

$0_{0}$

-

- 


\section{INTRODUCTION}

Glacier National Park consists of just over 1 million acres of which approximately 564,000 acres, or 57\%, are forested.

Numerous public facilities and roads as well as private homes are situated within these forests. Visitation continues to increase with more than 2,000,000 visitors using the park's roads and facilities. The potential exists for weakened trees or portions of trees to fall and cause injury to people and/or damage to property. Park management has a responsibility to reasonably protect visitors from unnecessary risks resulting from hazardous trees.

The purpose of Glacier National Park's Hazard Tree Management Program (HTMP) is to provide for the safety of people and property while protecting natural values. The Hazard Tree Plan (HTP) provides the guideline for assessing what trees represent a hazard; determining which facilities should be closed or relocated and which hazard trees should be removed; and assigning responsibilities for carrying out the program.

The objectives of the hazard tree program are:

1. Implementation of an aggressive, yet ecologically sound program that provides for regular prioritized surveys, evaluation of potentially hazardous trees and the removal or mitigation of tree hazards.

2. Preservation of ecosystem dynamics and structure, particularly the age classes and species diversity, while eliminating or mitigating hazards.

3. Consistency and continuity in tree hazard surveys, ratings, documentation, and evaluations of management alternatives.

\section{AUTHORIZATIOA}

The enabling legislation for the park as well as the organic Act of the National Park Service mandates the preservation of the biological and historical diversity while providing for enjoyment by the people. It is the policy of Glacier National Park to manage the park as a pristine natural area while providing reasonably safe recreational opportunities to the public.

Impetus for the hazard tree program derives from aspects of liability. The Federal Tort Claims Act-1 46 (28 USC 2671-80 and 1346 [b]) provides the basis for the National Park Service to be held liable for failure or negligence with respect to visitor protection. Most interpretations of tort law make the landowner responsible for taking reasonable care to avert harm to visitors. Reasonable care may take the form of actions (closing the site, 
moving a structure, removing the tree or parts of the tree) or warnings (public information and interpretive programs, handouts, postings, emergency procedures). Assumed risk by the visitor and leaving wild areas unaltered are not acceptable reasons for retreating from agency responsibility.

\section{COMPLIANCE}

The Hazard Tree Management Plan and subsequent program supplements the Resource Management Plan. Individual Environmental Assessments may need to be prepared for specific projects if they involve large scale or controversial activities. special concerns may include rare and endangered species or their critical habitat, impacts to visual resources or cultural landscape values, impacts to soils and hydrology, significant alteration of local natural forest structure and composition, wildlife nesting or breeding periods, surface disturbance of archaeological sites, and/or cumulative effects of ongoing programs or extended projects.

\section{PROCEDURES FOR OPERATIOMB}

Although it is impossible to predict when sound trees will fall, it is possible to determine when trees have sufficient disease or other defects that make tree fallure likely. A hazard tree exists when a tree or portion of a tree is in imminent danger of falling, due to disease or structural fallure, and striking a person object, structure, or vehicle. Not all trees with diseases or structural defects are hazardous, only those that are significantly weakened. Trees out of falling distance to humanuse areas, regardless of their condition, are not hazards because there is no target.

Trees with no detectable defects may fall during extreme wind events or due to unknown causes. The only way to eliminate all probability of damage by trees would be to remove all trees within human-use areas. This clearly counters the mandates and would decrease the quality of visitors' experiences.

This Hazard Tree Plan provides a procedure to identify hazard trees, select management actions, reduce the hazard and incorporate ecological concerns. Since there are some program revisions identified in this plan, it is necessary for employees to work closely with the staff Ecologist and Natural Resource Specialist (Field Resources) to ensure strategies are implemented as intended. The plan includes five actions (see Decision Tree, Appendix B):

- Write an Annual Work Plan.

- Survey to identify hazard trees.

- Select a mitigation action.

- Implement the mitigation action.

- Document Work 
The first year of implementation of this program will be critical to determine its effectiveness and practicality. During the first year, the Natural Resource Specialist (Field Resources) and the Ecologist will work closely on surveys and selection of mitigation actions. This will enable evaluation of the rating criteria and the feasibility and interpretation of the rating system. Additionally, it can be determined if the mitigation actions as outlined effectively meet the visitor safety and ecological objectives. The program will be modified as necessary prior to development of the following year's annual work plan.

\section{A. Annual Tork Plan}

The Natural Resource Specialist (Field Resources) coordinates the program as the Hazard Tree Team Leader. He/she organizes a Hazard Tree Work Team of employees from the Resources Management and Maintenance Divisions, and writes an Annual Work Plan. The goals, objectives and activities for each year are prioritized by the team based on funding, priorities, capabilities, and the previous years ecological evaluation. Following review and comment by the Park staff, the Annual Work Plan will be signed by the superintendent.

The Natural Resources Specialist (IPM and Forestry) leads implementation of The Annual Work Plan, which includes:

1. Pending mitigation actions from previous surveys.

2. Trees that need to be reexamined.

3. Identification of areas for spring surveys.

4. Approved mitigation actions from spring surveys.

5. Vegetation rehabilitation actions that are pending.

6. Assignment of responsibilities and schedules for work accomplishment.

7. Identification of informational needs.

8. Monitoring needs.

Considerations to use in setting priorities are based on management zone designations. For the purpose of this plan, the park is divided into four different management zones based primarily on the amount and type of human use and development in each area. Within each zone are sub-areas, e.g. Apgar Campground, that have specific targets, including people, property and facilities that are referred to in the Annual Work plan.

Developed 7one, Priority 1: Surveys are conducted annually in the spring, before facilities open. Areas within this zone are frequently used by visitors and employees with the highest probability of injury or property damage. The Park has encouraged visitors and employees to use and remain in these areas for travel, services, lodging, and recreation with a reasonable expectation of safety. Most visitor facilities are 
campgrounds, visitor centers, lodging facilities, roads, housing areas.

Historic Zone, Priority 2: Surveys are conducted biennially in the fall. Areas are of cultural significance with limited to moderate human use with some potential for injury or property damage. Some of the historic buildings in this zone may be irreplaceable structures. Examples include backcountry cabins and old homesteads.

Special Use zone. Priority 3: Surveys are conducted biennially in the fall. Areas are used by other agencies or companies (power and phone lines) which have some potential for injury or property damage. This zone contains other types of land ownership and leases identified in the Land Protection Plan. The Park will usually not conduct surveys or take mitigation action on these lands unless requested to assist as a consultant. The land owner has responsibility for the mitigation of hazard. Use of the area is based on carrying out the special use permit. Private land owners control access to their property. Examples include railroad, powerline, phone lines, private lands.

Natural zone, Priority 4: Surveys are conducted annually in the summer in areas of sporadic visitor use on a limited basis with low potential for injury or property damage. Inspections will be confined to areas with developed facilities such as backcountry campgrounds. Due to the number of miles of trails (730) in the Park and the very low residence time of humans in one spot on a trail, hazard tree surveys will not be conducted for trails. However, normal trall-clearing operations will remove trees hung up or leaning over trail corridors.

\section{B. Burvers to Identify Hanard Treen}

Yearly survey objectives are included in the Annual Work Plan formulated by the Hazard Tree Work Team. These note the type, time and staff responsibilities for the surveys. These objectives take into consideration frequency goals, recent notable weather events, past surveillance history and available funding for survey personnel and mitigation. It also includes a list of qualified personnel for the types of surveys prescribed (surveiliance or examination). Even though certain qualifications are required for surveys, all park employees are encouraged to report potential hazard trees to the Natural Resource Specialist (Field Resources) for investigation. 
There are two types of forest surveys used to identify hazard trees.

1. Surveillance surveys provide general oversight by walking or driving through an area and visually scanning the forest to detect potentially hazardous trees. Reports of potentially hazardous trees are reported to the Hazard Tree Team Leader by any park employees, concession employees or visitors (refer to Section IV.E, Document Work, and Appendix E). Surveillance may be part of a regular yearly work program, a normal part of spring opening, or occur after some wind events or snowstorms during the season. They may be conducted by trained members of the Hazard Tree Work Team.

During the survey, all trees that have recently failed (in the last storm or during winter) are noted. Species, size and suspected cause of failure are noted. When the number of fallen trees exceeds the time capabilities of the general surveyor, the trees are documented during the detailed examination. with this information we can determine the following: specific sites with tree fallure problems, probability of tree failure by species, common cause of tree failure by species, and seasonality of tree failure. This data will be used for risk assessments, tailoring the Annual Work Plan towards problem areas, and long-term analysis of forest dynamics and human impacts.

Some forest habitat types have persistent problems with tree failures that require close monitoring. For example, cedar/hemlock forests with older age class trees are known to have extensive heart rot, especially in henlock. Old-growth Douglas fir forests are known to have heart rot and root rot problems. Some uniform age stands of medium to older age lodgepole have mortality due to mountain pine beetle and windthrow. Therefore priority should be given to developments in and around these forest types.

2. Examination surveys are conducted by a trained hazard tree team member under the direction of the Natural Resource Specialist (IPY/Forestry). They are done concurrently or as soon after a surveillance inspection as is possible. Exaninations are systematic, specimen by specimen evaluations of all potentially hazardous trees identified in the surveillence Reports. The purpose of examination surveys is to make a risk assessment of detectable hazard trees to people and property. The examination and rating include species identification, description, measurement, defect assessment, wildlife use, hazard rating, mapping, tagging and documentation of location. The examiner may choose to rate the hazardous portion of the tree, rather than the whole tree, ie. dead top or branches. 
The hazard rating system is used to evaluate potentially hazardous tree conditions, and provide a guide for making decisions on mitigation methods. It is an assessment of risk that considers the probability of damage to a target. It also takes into account the target value. The hazard rating system is comprised of analysis of these factors, which are added as points in a two-part assessment. The results of all examinations are recorded on the Hazard Tree Examination Form (Appendix E), and kept on file in the Natural Resource Specialist (Field Resources) office at headquarters. All trees that have a hazard rating of 5-7 will be marked with a metal tag that is nailed to the base of the tree. Trees with a lower rating may be marked for future inspections. This tag has a unique identifying number that corresponds to the tree description on the record form. Based on the examination survey, interim warnings or closures may be put into effect.

Each tree will be carefully surveyed for presence of defects. Trees with defects will be rated low, medium, or high (1-3), as to their likeliness of fallure during the current season (USDI, 1991). An extra point may be added if a tree exhibits other defects in addition to structural problems (1.e. lean). Trees with no defects will automatically fall into the no hazard catagory. If a tree has fallen, the suspected cause of the fall as well as any defects will be noted. Documentation on species, size, any defects present and cause of fallure or date of removal will be maintained on each tree. The potential target will also be rated low, medium, or high (1-3) according to the value of the structure and/or human-use levels. Defects and guidelines for rating are below (modified from Wallis, Morrison and Ross, 1980).

\section{Tree Fallure Potential}

A tree will be rated as to its potential for failure as follows:

0 - minimal potential for fallure, no defects present

1 - low potential for fallure, some minor defects present

2 - medium potential for failure, moderate defects present

3 - high potential for fallure; dead trees, trees with serious defects, and those with multiple derects

4 - very high potential for fallure, a tree with several serious defects and a lean resulting from causes other than natural growth

Appendix C provides guidance for determining tree failure potential. 


\section{Impact to Target}

This rating considers the potential impact to a target if a tree were to fall on it. Included in this rating is the size of the tree or parts thereof, the probability of it hitting a target (appendix D), and the value of the target.

1 - minimal damage potential; probability of hitting target low, tree or parts thereof that could fail are small, target of low value, infrequent human use.

2 - moderate damage potential; medium probability of hitting target, tree or parts that could fail are of sufficient size to cause moderate damage, target could sustain some damage or is of moderate value, moderate human use.

3 - extensive damage potential; probability of hitting target high, tree or parts that could fail are of sufficient size to injure, kill or cause extensive property damage; targets include people and/or their property or high value public facilities, high human use.

In some instances, there will be conflicts in the potential rating. For example, a tree has a high probability of hitting the target, but the target is of low value and infrequently used and the parts of the tree that could strike the target are of moderate size. The examiner must balance the various issues to determine a rating. In the above case, the rating would be a 1 or 2 depending on the actual value and purpose of the target. 


\section{Hazard Tree Rating}

The two ratings are added together to obtain an overall rating to determine hazard level and management action according to the following chart. Hazard determination and recommended action (modified from NPS-77, 1991).

$\begin{array}{ll}\text { Rating Hazardous Condition } & \begin{array}{l}\text { No discernible flaw and no } \\ \text { construed risk - not a } \\ \text { hazard }\end{array} \\ \text { Low - not a hazard } \\ 3-4 & \text { Medium - not a hazard } \\ 5-7 & \text { High - hazard }\end{array}$

Recommended Action

No immediate action needed

No immediate action needed.

Monitor annually or as recommended, but do not remove, or mitigate.

Top or remove the tree or defective $l i m b(s)$ or move the target, or close the site.

Mitigation actions will be prioritized based on hazard rating. For example, actions will be implemented on trees with 7 rating before trees with 5 rating. Trees that are not hazards (i.e. those with no defects or with defects but not likely to fall) should be monitored annually in high use areas and less frequently in lower use areas to detect any changes in their condition that may change their status to a hazard.

\section{c. Belect Mitigation Action}

The Natural Resources Specialist (Field Resources) coordinates the use of the Hazard Tree Management Plan Decision Tree to select alternatives for reducing risk from trees judged hazardous during the examinations. He/she is ultimately responsible for selection of a preferred alternative or obtaining a staff decision when necessary (see below). Selection of a mitigation action considers the prescribed criteria and coordination with Team Members.

Trees that are not hazards (i.e. trees with defects but not in imminent danger of falling and striking a target) are monitored to detect changes in their condition. Trees that are judged hazard trees require mitigation measures as soon as possible following the examination. Areas within striking distance of a hazard tree will be signed and closed to the public until full consideration of possible actions and removal of the hazardous conditions is completed. 
There are three management actions to eliminate the hazard from trees:

1) the tree may be removed

2) the target may be moved, or the area closed to human use

3 ) the hazard portion of the tree may be removed

vitigation alternatives must consider:

1. Aesthetic and historic values of the tree.

2. Ecologic value of the tree including wildlife forage and nesting, vegetation community dynamics (shading, seed source, etc.) and potential for windthrow following removal.

3. Number of trees recommended for removal and number of trees removed in previous years within the area.

4. Forest community, site conditions, susceptibility of site to having hazard trees, and species of trees.

5. Historic, social, and monetary value of the target.

6. Feasibility of closing the area or moving the target.

7. Management zone and the type and amount of visitor use in the area.

All reasoning for the final management decision must be well documented on a tree rating form. Staff review is mandatory for certain mitigation decisions and is handled through the Park Planning Process, Management Directive 15.1. At this point a specific time period for review is set. The mitigation decision will then be made by the Park Management Team.

\section{Mandatory reviow decisions include:}

1. Closure of facilities permanently or for an extended period of time. This may result from inability to remove the hazard or move the facility or temporary wildife activity such as nesting birds.

2. Relocation of a target requiring extensive cost and/or planning (e.g. parking lot, campground, etc.).

3. Removal of trees when such removal results in a 10 or more loss of standing trees within the immediate environment.

4. Removal of known endangered species perch or nesting trees. Absent these conditions (1-4) mitigation action may proceed with the approval of the Natural Resource Specialist (Field Resources). 


\section{Implement Kitigation Action}

If a decision is made to remove hazard tree(s), all provisions for public safety, crew safety, sawyer skill level, and the removal of debris must be met. Cutting, removal of the tree and cleanup is coordinated by the Hazard Tree Work Team, as agreed upon in the Annual Work Plan. The Natural Resource specialist (IPM \& Forestry) is responsible for timely implementation of the selected action, and coordination with other activities such as campground opening and facility maintenance.

The number of trees removed each year may vary dependent on budgetary and personnel constraints. Contract and cyclic maintenance funds may be requested for the removal of trees. list of qualified sawyers from the Maintenance and Resources Management Divisions is maintained by the Hazard Tree Work Team to utilize for tree removal throughout the park.

When high winds or other conditions threaten visitor safety due to hazards posed by falling trees or limbs, protection actions such as road, site or campground closures and the evacuation of visitors to safety areas may need to be taken. Closures and evacuation are addressed in the Emergency Evacuation Plan and are the responsibility of the District Rangers. Developed sites may be closed temporarily following severe wind storms until adequate surveys can be completed and mitigation carried out if necessary.

Temporary site closures are coordinated by the District Ranger. Seasonal or permanent site closures and/or moving of facilities are reviewed and approved by the management staff.

\section{B. Document rork}

Documentation is essential for any resource decision or manipulation that may lead to tort claims or scrutiny by interest groups or the general public. Additionally, detailed documentation assists in analyzing and improving the program. Computer software is developed to track potential hazard trees and initiate a database for program improvement.

The following documentation is maintained for the hazard tree management program. Please refer to Appendix E.

1. Trees identified during surveys are recorded on the "Hazard Tree surveillance Record" form. Information in reports includes tree location, description of defect, species, estimated height and width, description of target and action recommended. These reports are submitted to the Natural Resource Specialist (Field Resources) in headquarters for evaluation. Surveillance reports are compiled and summarized on Case Incident Reports 10-343 by the Natural Resource Specialist. Potential hazard trees may also be recorded on maps of the developed area, with supporting 
information.

2. Examination Surveys are recorded on the "Hazard Tree Examination Record" form. The form includes documentation of detailed inspections, results of criteria rating, decision on mitigation and date of implemented mitigation. Mitigation action is not implemented until information from the inspection is completed. Examination reports and resulting actions are summarized on Supplemental Case Incident Record 10-344 by the specialist.

3. Training courses and seminars attended by Hazard Tree Work Team members are documented in memorandum by the Hazard Tree Team Leader, and also recorded on a training form for the employees personnel file.

4. Tree fallures that are not identified on Surveillance or Examination forms are recorded in the Report of Tree Failure.

5. All tree records will be maintained in a computer data base, updated each fall. The data base will be used to track trees and make ecological evaluations of the program. The Ecologist, working with the Natural Resource specialist (Field Resources) and the Computer Specialist, will design and manage the data base.

\section{BITB REHABIITTATION NMD / OR MOMITORIMO}

One of the ecological concerns with any tree removal program is the disruption of the natural community structure. In many cases, tree hazards occur in a well-developed forest with canopy and understory vegetation. Removal of a few hazard trees is not a significant disruption to the natural community. However, some sites suffer from heavy use which precludes development of understory vegetation (e.g. Lake McDonald lodge and complex). As trees die and/or are removed, there are no young trees to replace them. Eventually, the area does not have any overstory and is converted from a forest to a open grassland, shrub, or barren area. In areas where there is no understory, a rehabilitation plan should be developed which compensates for the long-term impacts of hazard tree removal. Canopy management strategies are to be included in the Vegetation Management Plan, currentiy under formulation.

The overall number of hazard trees previously removed is evaluated annually to detect and prevent undesired cumulative effects. Additionally, an assessment of the accuracy and reliability of the tree rating and rating criteria is conducted as funding becomes avallable. Reviews are conducted by the Natural Resource Specialist (field resources) and the Ecologist in the Resources Management Division. 


\section{PUBLIC INFORMATION}

It is important to communicate the goals and provisions of this plan to the staff through training programs, notices and individual contacts. This is especially important when removal projects are imminent or underway. It is critical to inform the interpretive staff, the Public Information officer and other ranger and maintenance personnel who are working in or near the affected area.

The public should be informed where mitigation actions are occurring that may affect their activity planning. If tree removal is planned within facilities that are open, adequate signing and information is posted before actions are implemented.

\section{ROLES AND REBPONBIBILITIEB}

\section{A. Resources Yanagement Division}

1. The Natural Resource Specialist (field resources) is the Hazard Tree Team Leader. He/she organizes a Hazard Tree Work Team composed of the District Rangers and the Facility Managers. The Work Team reaches consensus in planning the goals, objectives and activities for the year in an Annual Work Plan. He assists with public information and provides assistance in modification of the hazard tree management plan.

2. The Natural Resource Specialist (Forestry \& IPM) coordinates supervision of survelllance and examination surveys, selection of mitigation actions, staff review when required, removal of hazard trees and cleanup. He/she assesses personnel qualification levels for surveys and tree removal, and coordinates training. A seasonal supervisory park ranger will lead field crews to implement the work, likely composed of employees from several divisions.

3. District Rangers participate as partners on the Work Team, and recommend priorities for surveys and mitigation. Subdistrict personnel assist with implementation of the Annual Work plan, as assigned by the District Ranger. Seasonal personnell may include frie crews and hazard fuel crews. Duties may include surveillance, felling trees or cleanup. They are responsible for informing visitors of significant weather events that could increase the hazard from trees and posting notices or signs and implementing the Emergency Evacuation Plan when needed.

4. Wilderness Manager and backcountry staff conduct surveys and mitigation at designated campsites and developed facilities within the backcountry and proposed wilderness.

5. Trails Foremen and crews may assist with surveys and mitigation within the backcountry and proposed wilderness. They 
may be requested to fell hazard trees within developed areas.

6. Ecologist is primarily responsible for evaluation and modification of the hazard tree management plan. This includes ecological evaluation of work completed to determine long-term impacts, development and evaluation of rating criteria, modification of mitigation selection factors, and development of computer software. The ecologist develops and conducts research to improve the program. He/she reviews the annual work plan and provides technical assistance. In fall, the Ecologist prepares an annual ecological evaluation of the program and makes recommendations for modifications or management actions.

\section{B. Maintenance Division}

1. Facility managers participate as partners on the Hazard Tree Work Team to suggest priorities, plan work for the comming season and determine the level of assistance that can be provided. Maintenance crews participate in a support role with rangers in cutting of hazard trees or removal of debris from developed areas. The amount of time spent on hazard trees is dependent on funding, weather, scheduling and location.

2. The Landscape Architect reviews the annual work plan.

\section{Interpretation piviaton}

1. Interpretors may submit informal reports of potentially hazardous trees to the Hazard Tree Team Leader whenever they observed a tree that may be a hazard. They provide interpretation of hazard tree removal as necessary within campgrounds and developed areas.

\section{E. Iandse safetre concerstons}

1. Hazard trees may be reported to the safety officer or District Safety Committees by any employees in a given area using the Hazard Condition Report. This record is maintained by the Safety officer in computer flles. The Safety officer is a technical consultant regarding compliance of the program, and safety issues involved in mitigation methods.

2. The concessions specialist provides assistance in implementing this plan with the variety of concession operations in the Park.

\section{F. Training}

It is critical for employees involved in the hazard tree management program to have training in particular skill areas related to specific tasks. 
For surveillance but particularly examination surveys the following skill areas and types of training are important:

a. Basic silvicultural and vegetation management principles; ecological relationships linking vegetation, insects and disease; arboricultural techniques and equipment; basic training in botany, dendrology, and/or plant pathology; Glacier National Park forest ecology and habitat types.

b. Attendance at a Tree Hazard Identification training course to train personnel to identify/evaluate tree defects, use the rating system, and recommend mitigation action; development and use of a detailed defect/hazard diagnostic key.

c. Attendance at arboriculture workshops where tree care, hazard treatment procedures and equipment use are taught; pest management seminars including insect and disease identification;

For employees involved in removal or limbing:

a. Technical training in chainsaw operations, including felling and climbing techniques, and equipment maintenance; certification may be required for chainsaw operators and fellers in some situations.

b. Safety training for protecting the public and other crewmembers while felling, bucking, limbing or removal operations are occurring.

c. Employees with chainsaw certification following completion of forest fire training course $\mathrm{s}-212$ will be utilized in hazard tree removal.

The Natural Resource Specialist (Field Resources) will be responsible for developing programs to enhance staff expertise and coordinating training. This may be done by utilizing consultants, cooperative opportunities with other agencies or arranging specific training courses. 


\section{STAFFING CHART}

RESOURCES DIVISION 1994

Hazard Tree Program

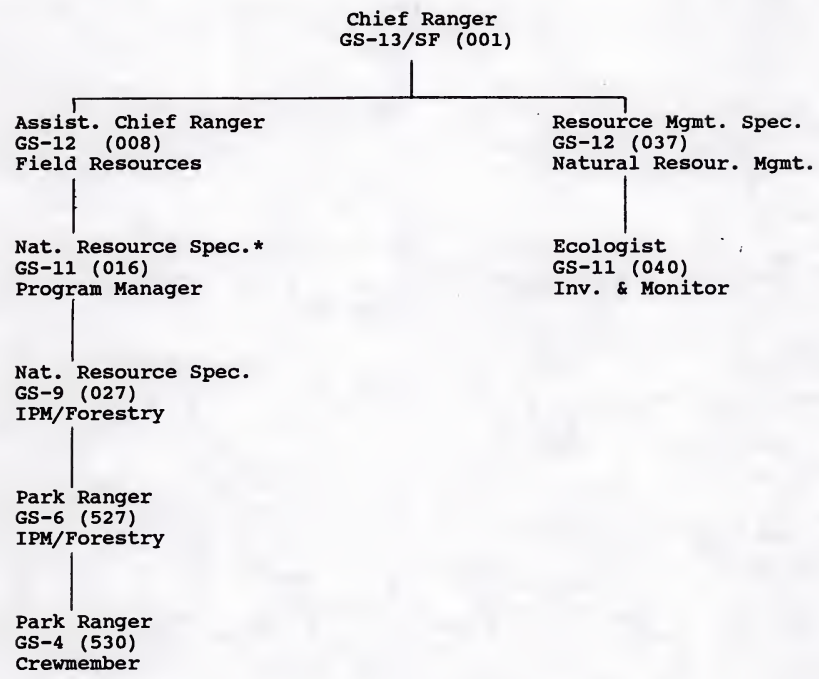

*Hazard Tree Team Leader 
0

-

○

-

0

$C_{0}$

-

.

0

- 
APPENDIX A -DEFINITIONS

Human-use area - Any park area that has been developed specifically for human use. This includes regularly maintained trails, roads, visitor facilities, residences and work areas. The undeveloped, off-trail/road areas of the park are not included.

Tree hazard - A tree or portion of a tree that has common detectable defects that sufficiently weaken a tree so that it is in imminent danger of falling in a human-use area and causing damage to a person or object.

Defect - Any detectable character of a tree that may detract from the normal growth of the tree. Examples include irregular growth patterns, disease, rot, and death of the tree or portion of the tree. A defect may be natural or human caused. Natural defects are recognized as part of the ecosystem and are not considered in a negative light.

Target - Any person(s) or property that may sustain injury or damage from falling trees.

Hazard Rating Bystem - A decision making process that is used to assign a value of risk to a tree based on the probability of tree failure, and the probability of extensive damage to a target. The cumulative point total falls within score ranges that define the condition. 
0

-

○

-

-

0

-

.

-

0 
Annual work plan completed

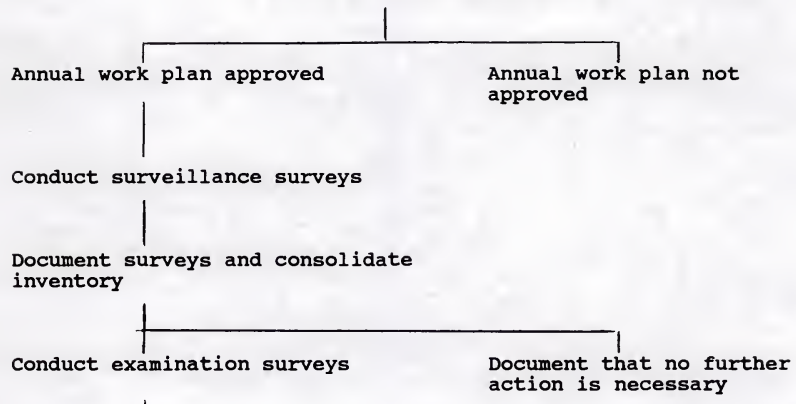

Compute risk assessment and.

hazard rating of trees

Hazard trees identified

No hazard trees identified

$\mid$

Map and mark hazard trees

Document that no further action is necessary, or trees that need to be monitored in the future

(continued on next page) 


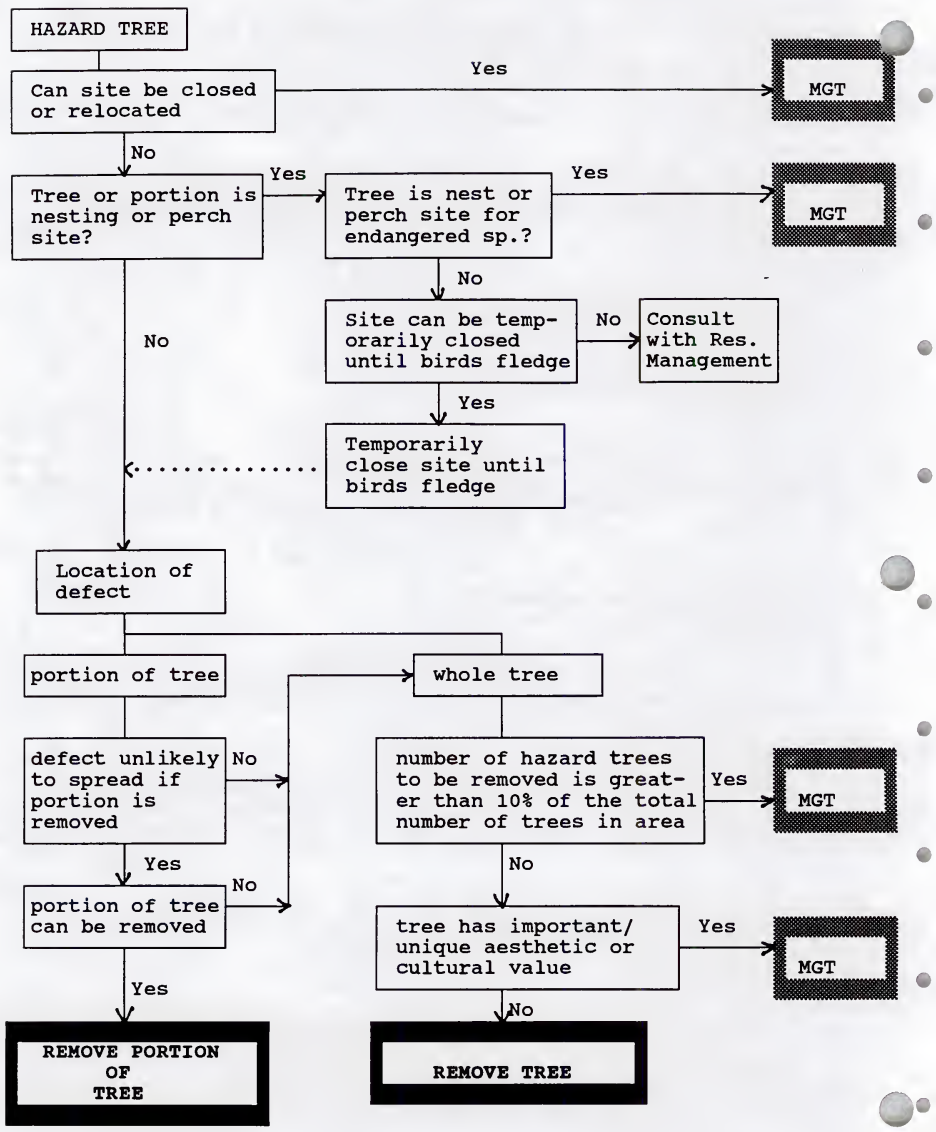


APPENDIX C - TREE RATING CRITERIA USED IN DETAILED EXAMINATIONS

The criteria is a standard on which a decision is based to rate hazard trees using characteristic marks or traits of the tree. criteria used to identify a hazard tree include observable defects in tree condition that result in high risk for failure, and potential of the tree to strike a target when it falls.

Each tree will be carefully surveyed for presence of defects. Trees with defects will be rated low, medium, high or very high (1-4), as to their likeliness of failure during the current season (USDI, 1991). Trees with no defects will automatically fall into the no hazard category.

The potential target will also be rated low, medium or high (1-3) according to the value of the structure and/or human-use levels.

\section{A. Tree Evaluation Factors:}

Examinations of the potential hazard trees identified in surveillance surveys must be done systematically. All observed defects are documented. Factors used to rate tree condition include:

1. External condition and appearance

2. Occurrence and extent of heart rot

3. Amount of sound wood remaining

\section{External Condition}

Johnson (1981) lists the following defects in order of importance to be noted on trees. These are observable conditions that can be documented during the examination survey, and evaluated.

1. Dead trees

2. Leaning trees

3. Root injuries

4. Crown injuries

5. Insect Activity

Weakness in the tree can result from physical injury, disease or insect activity. Two or more defects occurring together may sometimes render a tree hazardous when it might not be if it had only one defect. Examples include the combination of a sap rot and a heart rot, or one of a leaning tree with a large basal wound in line with the direction of lean. Other combinations are possible and should be looked for in the course of inspections.

Detailed information regarding types of diseases and tree species specific problems can be found in various publications (Hagle, et.al., 1987, Larson, 1984; Johnson, 1981; Hamilton and Edwards, 1976; and Wagener, 1963). It is recommended that the observer use these reports to be familiar with species specific problems. It is not the intent of this plan to replace technical references 
used in field examinations. These field guides are important references to use in documenting tree condition. Since there is interest in the criteria used to predict tree failure, it may be helpful to list factors are indicators of high risk for failure.

Tree defects to watch for that are indicators of high failure potential are listed in table 1. 


\section{LOCATION OF \\ FAILURE}

DEFECT

\section{WHOLE TREE FAILURE}

\section{ROOT AND BUT} FAILURE

\section{BUTT ROT
(declduous) \\ - CANKERS (conifors oxcep ceder ond deciduous) \\ - DWARF MISTLETOE (conifor sxcept ceder) \\ FOLIAGE (conifer except ceder) \\ - FROST \\ (conifer except \\ ceder) \\ - FRUITING \\ BODIES (conifors except coder) \\ - FRUITING BODIES (in ceder end \\ - HOLlOW BUTT (conifer except ceder) \\ - HOLLOW \\ BUTT \\ ceder) \\ - HOLlOW \\ BUTT \\ (deciduous) \\ - MYCELIUM (conifor except ceder)}

\section{LOW FAILURE POTENTIAL}

Decey in butt confined to smell, locelized oree. Decey extensive throughout the heertwood In the butt.

Butt cenkers with the berk still intect.

Young dwerf mistletoe swelling In butt.

Frost crecks with little or no essocieted edvenced decey.

Hollow butt if less then e querter of the stem is affected.

hollow butt provided less then helf of the circumforence of the stem is effected.

Hollow in butt confined to e smell section of stem.

Phellinus weirii mycelium on the roots but no stein or decey in the butt.

\section{HIGH FAILURE POTENTIAL}

\section{Deed trees}

Loening trees growing on sites with e high weter teble.

Butt cenkers effecting e mejor portion of the circumference of the stem end with much of the cenker tissue deed.

Dwerf mistletoe swellings in the butt, perticulerly if essocleted with edvenced decey.

Thin chlorotic foliege indicetes a tree is dying es e result of root rot or other diseese.

Frost crecks with extensive essociated edvenced decey.

Fruiting bodies on the butt of the tree, or on the ground eround the tree.

Fruiting bodies on lower bole.

Hollow butt if e mejority of the stem is deceyed.

Hollow butt with more then $\theta$ half of the circumference of the stem effected and with significent edvenced decey.

Hollow in butt effecting e mejor portion of the circumference of stem.

Phellinus weirii mycelium on the roots end red-brown stein end/or decey in the butt. 


\section{LOCATION OF FAILURE}

ROOT AND BUTT FAILUR

STEM FAILURES
- MYCELIUM

(deciduous)

- PAVEMENT

- RESIN

(conifer excep

cedar

- ROOTS

- SOIL

- WOUNDS

- WOUNDS

(conifers excep

coder)

- WOUNDS

(deciduous)

- BURLS

(deciduous)

- CANKERS

(ponderose pine)

- DWARF

MISTLETOE

(conifer except

ceder) *

- FORKED

STEMS

(conifer except

ceder)

- FORKS

(ceder)

FROST

- FRUITING

BODIES

\section{LOW FAILURE POTENTIAL}

Mycelium below the bark near the ground line confined to less than $\theta$ half the circumference of the stem.

Pavement, asphalt, over roots; not hazerdous in itself but fevors the development of hezerdous conditions.

Resin flow from the butt near the ground line, with less then a helf the circumference of the stem affected.

Fow small roots severed or injured.

Cracks or heaving in soil eround tree indicating recent movement.

Scer with little wood injury.

Root and butt wounds less than 5 years old provided there is little edvenced decey.

Young small basal scars with little or no associeted advanced decay.

Burls or galls

Cankers, horizontal, when low on trunks.

Dwarf mistletoe stem canker with the bark still intact.

Forked stems, one or both fork being of a small diemeter.

Forks and crooks.

Frost cracks.

One or two small fruiting bodies in the upper stem.

\section{HIGH FAILURE POTENTIAL}

Mycelium below the bark neer the ground line effecting most of the circumference of the stem.

Resin flow from the butt near the ground line, with most of the circumference of the stem effected. Mycelium fans below the bark.

Most of the roots on one or more sides of the tree severed or badly demeged.

Scar with the wood deeply gouged, possibly fractured.

Root and butt wounds more then 10 years old and with extensive advanced decey.

Basal scar with extensive associated advanced decay.

Cankers, horizontal, when deep end above 16 feet from the ground.

Dwarf mistletoe stem cenker with more than a half the circumference dead.

Large, long, and heavy forked stems joined part way up the stem. The crotch of the fork is at right engles to the direction of heaviest winds.

Multiple fruiting bodies along length of stem. 


\section{LOCATION OF \\ FAILURE}

STEM FAILURE

DEFECT

- HEART ROT

(deciduous)

TREA LEA

- LEANING

TREE (conifers)

- LEANING

TREE

(dociduous) -

- TWIN STEMS

(csdar)

- WOUNDS

- WOUNDS

(conifer except

cedar)

- WOUNDS

(dsciduous)

\section{TOP AND BRANCHES}

\section{LOW FAILURE POTENTIAL}

Old lsan, uppsr ssction of stsm growing vartically.

Trees that have grown in a lsaning position.

Small twin stsms.

Scar with little wood injury

Scars lsss than 5 ysars old providsd wood not dssply gouged.

Young small scars with little or no associated dscay.Largs scars affecting major portion of

circumfsrsncs of stsm and with sxtsnsivs assoclated advancsd decay.

Sound crotch.

Broksn tops with adjecsnt branchss hsalthy.

Top and branch canksrs with ths bark otill intact.

Smell dsad branchss.

- DEAD

BRANCHES

codar and

- DEAD TOPS

(conifsr excspt

(conifs

- decar

(dsciduous)

Smell tops, dsad spike, on pines and Douglas-firs it old, without bark and dssply wsathered.

Branchss with littls or no dscay associated with crotch.

\section{HIGH FAILURE POTENTIAL}

Extsnsive heart rot, hollow stem

Rscsnt lsan, soil around trss cracksd or having indicating rscsnt movement.

Lsaning trses if (a) ths Isan has bsen caused by an outside forcs, or (b) an opsn wound with advanced dscay and poor celluses is in line with ths dirsction of Isan.

Leaning treas if the Isan is sxtreme and the lsverege grsat for ths strsngth of the wood.

Large twin stems joinsd part way up stam.

Scars with wood deeply gougsd, possibly fractured.

Scars mors than 5 ysars old and with sxtsnsive associated advanced decay.

Split crotch.

Broksn tops with adjacsnt branches unhealthy.

Top cankers whsrs most of the canker facs is dead.

Large dsed branchss, espscially if broksn and lodged in other branchss.
Largs tops and branches, dead on other species, or bark-covered on pins or Douglas-fir (includes dead volunteer tops).

Extsnsivs dscay in stem and lower portion of largs branches. 
LOCATION OF

FAILURE

\section{TOP AND BRANCHES}

\section{DEFECT}

DWARF
MISTLETOE
(conifer except

- FORKED TOPS

(conifer oxcept

codarl

- FRUITING

BODIES

(conifer excep

- MULTIPLE

LEADERS

- SPIKE TOPS

(cedar)

\section{LOW FAILURE POTENTIAL}

Small dwarf mistlatoe brench end top swellings and witches' broom.

Smell forked tops and crooks.

One or two smell fruiting bodies in top of stem.

Small, live and thrifty volunteer tops.

Spike top not weakened by woodpeckers or decay.

\section{HIGH FAILURE POTENTIAL}

Large dwerf mistlotoe, witches' brooms on branches.

Large forked tops.

Numerous fruiting bodies in top of stem.

Heavy U-sheped brenches formed when side brench

Spike top weakened by woodpeckers or decay.

- Main stem or trunk swellings, from stem infactions by dwarfmistlotoe when the host trees were young, may be quite provelent on true fire. As long as the swolling remlens alivo, It does not woaken the trunk, but oventually the camblum in the oldest pert of the swelling dlas. The bqerk over the doed part soon becomes broken, creating an open canker. Decay usually dovelops in

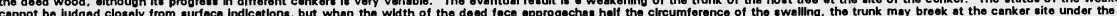

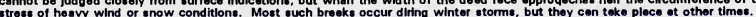

Open dwerfmistlotoe conkers are sometimes found on the lower trunks of ponderose pines, but the wood eround them becomes haevily resin-inflitreted, protecting them from decay. They do not appoer to contributo in any way to hazord.

- It is difficult to prodict fellure potentlel of loaning trees besed on the angle of loen. The cause of the lean must bo dotermined. A trae which has grown in a leaning position structurally

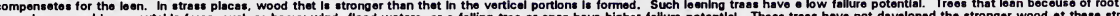
cos wound.

\section{MULTIPLE DEFECTS OR CONDITIONS}

Two or more defects occurring together mey sometimes render e tree hezerdous when it might not be if it had only one defect. Examples include th combinetion of a sep rot and a heert rot, or one of a leening tree with a large basal wound in line with the direction of leen. Other combinations are possible and should be looked for in the course of inspections. 


\section{B. Checking for Heart Rot}

One of the most common defects to look for and assess in trees is heart rot or hollowness of the trunk resulting from it. Expect this defect particularly in trees bearing conks or showing old wounds, either open or closed. Occasionally, however, an old tree will be hollow with little outside evidence of heart rot. Keep in mind that a tree need not be large to be hollow.

The rate of recent diameter growth is a useful index of the probable safety of any tree with heart rot or hollowness. Trees that are making good growth will have thicker sapwood than those growing slowly and should be less likely to fail. The condition of callus growth around wounds is also of indicator value. If growth of the tree is good, callusing will be good and the bark over the callus will be thin and healthy in appearance. The crown will also be thrifty.

One test for heart rot or hollowness of the lower trunk consists in "sounding" the trunk by striking it sharply with the poll of an axe. If hollow or decayed and the surrounding wood is not too thick, the blow on the trunk will produce a hollow sound distinguishable from that produced when a solid trunk is struck in this manner.

For a more positive method of testing for hollowness, sample the lower trunk with an increment borer. If the borer breaks through into rot or a hollow resulting from the collapse of rot, the extracted core will give the thickness of the surrounding wall of solid wood at that point and also an opportunity to judge the rate of recent growth. [When heart rot is suspected, a increment core will be extracted to determine the extent of the rot and the thickness of sound wood so that the hazard level can be determined. See 'judging the hazard' section below.]

\section{Amount of Sound Wood Remaining}

As mentioned above, the presence of any of the listed defects does not automatically constitute a hazard. Many trees are sound even though they may be hollow. The extent of tree weakening must be determined in order to determine the potential of failure.

In order to determine the strength of a tree with heart rot, an increment core is needed. A tree with heart rot may lose up to 70 percent of wood inside the bark without affecting its safety (Wagener, 1963). Table 1 gives the minimum thickness of sound wood needed to maintain various diameters of trees. 
Table 1. Minimum safe standard for defective trees applied as average thickness of outer sound wood of the trunk with center rot or hollow representing 70 percent of the total wood diameter, equivalent to one-third loss in strength. From Wagener, 1963.

Diameter of tree inside bark (inches)

16

20

24

28

32

36

40

44

48

52

56

60

64

68
Thickness of sound wood

(inches)

2.5

3.0

3.5

4.0

4.5

5. 5

6.0

6.5

7.0

8.0

8.5

9.0

9.5

10.0 


\section{APPENDIX D}

\section{DETERMINATION THE PROBABILITY THAT A TREE WILL HIT A TARGET}

Determination of the probability that a tree will hit a target is based on the lean of the tree, width of the target, and the distance the tree is from the target. Using the angle within striking distance tables, the probability levels can be determine using the following steps.

1. Does the tree have a structurally defective lean?

$$
\text { no. }
$$
use Table A go to step 2

yes-Does the tree lean toward the target?

$$
\begin{aligned}
& \text { yes..............................use Table } B \\
& \text { go to step } 2
\end{aligned}
$$

2. Find the maximum width of the structure across the top row.

3. Follow the maximum width column down to the distance the tree is from the object.

4. Determine where the angle falls in relation to the probability level lines:

below the single line. low probability

between the single and double lines..medium probability above the double line. high probability

Assumptions of the tables:

The tree is at the center of the width of the target and it would fall perpendicular to the target. For trees which this is not the case, the table will slightly overestimate the striking angles and resultant probability level.

The tree's height equals or exceeds the distance from the building. 
0

-

-

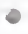

$0^{\circ}$ 
TABLE A FOR DETERMINING ANGLE WITHIN STRIKING DISTANCE

FOR TREES WITHOUT A LEAN

TARGET WIOTH

\begin{tabular}{|c|c|c|c|c|c|c|c|c|c|c|c|c|c|c|c|c|}
\hline & 1 & 10 & 20 & 30 & 40 & 50 & 60 & 70 & 80 & 90 & 100 & 110 & 120 & 130 & 140 & 150 \\
\hline 1 & 53 & 11457 & 169 & 172 & 174 & 175 & 176 & 177 & 177 & 177 & 178 & 178 & 178 & 178 & 178 & 178 \\
\hline 5 & 11 & 90 & 127 & 143 & 152 & 157 & 161 & 164 & 166 & 167 & 169 & 170 & 170 & 171 & 172 & 172 \\
\hline 10 & 6 & 53 & 90 & 113 & 127 & 136 & 143 & 148 & 152 & 155 & 157 & 159 & 161 & 163 & 164 & 165 \\
\hline 15 & 4 & 37 & 67 & 90 & 106 & 118 & 127 & 134 & 139 & 143 & 147 & 149 & 152 & 154 & 156 & 157 \\
\hline 20 & 3 & 28 & 53 & 74 & 90 & 103 & 113 & 121 & 127 & 132 & 136 & 140 & 143 & 146 & 148 & 150 \\
\hline 25 & 2 & 23 & 44 & 62 & $\pi$ & 90 & 100 & 109 & 116 & 122 & 127 & 131 & 135 & 138 & 141 & 143 \\
\hline 30 & 2 & 19 & 37 & 53 & 67 & 80 & 90 & 99 & 106 & 113 & 118 & 123 & 127 & 130 & 134 & 136 \\
\hline 35 & 2 & 16 & 32 & 46 & 59 & 71 & 81 & 90 & 98 & 104 & 110 & 115 & 119 & 123 & 127 & 130 \\
\hline 40 & 1 & 14 & 28 & 41 & 53 & 64 & 74 & 82 & 90 & 97 & 103 & 108 & 113 & 117 & 121 & 124 \\
\hline 45 & 1 & 13 & 25 & 37 & 48 & 58 & 67 & 76 & 83 & 90 & 96 & 101 & 106 & 111 & 115 & 118 \\
\hline 50 & 1 & 11 & 23 & 33 & 44 & 53 & 62 & 70 & $\pi$ & 84 & 90 & 95 & 100 & 105 & 109 & 113 \\
\hline 55 & 1 & 10 & 21 & 31 & 40 & 49 & 57 & 65 & 72 & 79 & 85 & 90 & 95 & 100 & 104 & 107 \\
\hline 60 & 1 & 10 & 19 & 28 & 37 & 45 & 53 & 61 & 67 & 74 & 80 & 85 & 90 & 95 & 99 & 103 \\
\hline 65 & 1 & 9 & 17 & 26 & 34 & 42 & 50 & 57 & 63 & 69 & 75 & 80 & 85 & 90 & 94 & 98 \\
\hline 70 & 1 & 8 & 16 & 24 & 32 & 39 & 46 & 53 & 59 & 65 & 71 & 76 & 81 & 86 & 90 & 94 \\
\hline 75 & 1 & 8 & 15 & 23 & 30 & 37 & 44 & 50 & 56 & 62 & 67 & 73 & 77 & 82 & 86 & 90 \\
\hline 80 & 1 & 7 & 14 & 21 & 28 & 35 & 41 & 47 & 53 & 59 & 64 & 69 & 74 & 78 & 82 & 86 \\
\hline 85 & 1 & 7 & 13 & 20 & 26 & 33 & 39 & 45 & 50 & 56 & 61 & 66 & 70 & 75 & 79 & 83 \\
\hline 90 & 1 & 6 & 13 & 19 & 25 & 31 & 37 & 43 & 48 & 53 & 58 & 63 & 67 & 72 & 76 & 80 \\
\hline 95 & 1 & 6 & 12 & 18 & 24 & 29 & 35 & 40 & 46 & 51 & 56 & 60 & 65 & 69 & 73 & 77 \\
\hline 100 & 1 & 6 & 11 & 17 & 23 & 28 & 33 & 39 & 44 & 48 & 53 & 58 & 62 & 66 & 70 & 74 \\
\hline 105 & 1 & 5 & 11 & 16 & 22 & 27 & 32 & 37 & 42 & 46 & 51 & 55 & 59 & 64 & 67 & 71 \\
\hline 110 & 1 & 5 & 10 & 16 & 21 & 26 & 31 & 35 & 40 & 44 & 49 & 53 & 57 & 61 & 65 & 69 \\
\hline 115 & 0 & 5 & 10 & 15 & 20 & 25 & 29 & 34 & 38 & 43 & 47 & 51 & 55 & 59 & 63 & 66 \\
\hline 120 & 0 & 5 & 10 & 14 & 19 & 24 & 28 & 33 & 37 & 41 & 45 & 49 & 53 & 57 & 61 & 64 \\
\hline 125 & 0 & 5 & 9 & 14 & 18 & 23 & 27 & 31 & 35 & 40 & 44 & 47 & 51 & 55 & 58 & 62 \\
\hline 130 & 0 & 4 & 9 & 13 & 17 & 22 & 26 & 30 & 34 & 38 & 42 & 46 & 50 & 53 & 57 & 60 \\
\hline 135 & 0 & 4 & 8 & 13 & 17 & 21 & 25 & 29 & 33 & 37 & 41 & 44 & 48 & 51 & 55 & 58 \\
\hline 140 & 0 & 4 & 8 & 12 & 16 & 20 & 24 & 28 & 32 & 36 & 39 & 43 & 46 & 50 & 53 & 56 \\
\hline 145 & 0 & 4 & 8 & 12 & 16 & 20 & 23 & 27 & 31 & 34 & 38 & 42 & 45 & 48 & 52 & 55 \\
\hline 150 & 0 & 4 & 8 & 11 & 15 & 19 & 23 & 26 & 30 & 33 & 37 & 40 & 44 & 47 & 50 & 53 \\
\hline 155 & 0 & 4 & 7 & 11 & 15 & 18 & 22 & 25 & 29 & 32 & 36 & 39 & 42 & 46 & 49 & 52 \\
\hline 160 & 0 & 4 & 7 & 11 & 14 & 18 & 21 & 25 & 28 & 31 & 35 & 38 & 41 & 44 & 47 & 50 \\
\hline 165 & 0 & 3 & 7 & 10 & 14 & 17 & 21 & 24 & 27 & 31 & 34 & 37 & 40 & 43 & 46 & 49 \\
\hline 170 & 0 & 3 & 7 & 10 & 13 & 17 & 20 & 23 & 26 & 30 & 33 & 36 & 39 & 42 & 45 & 48 \\
\hline 175 & 0 & 3 & 7 & 10 & 13 & 16 & 19 & 23 & 26 & 29 & 32 & 35 & 38 & 41 & 44 & 46 \\
\hline 180 & 0 & 3 & 6 & 10 & 13 & 16 & 19 & 22 & 25 & 28 & 31 & 34 & 37 & 40 & 43 & 45 \\
\hline 185 & 0 & 3 & 6 & 9 & 12 & 15 & 18 & 21 & 24 & 27 & 30 & 33 & 36 & 39 & 41 & 44 \\
\hline 190 & 0 & 3 & 6 & 9 & 12 & 15 & 18 & 21 & 24 & 27 & 29 & 32 & 35 & 38 & 40 & 43 \\
\hline 195 & 0 & 3 & 6 & 9 & 12 & 15 & 17 & 20 & 23 & 26 & 29 & 32 & 34 & 37 & 39 & 42 \\
\hline 200 & 0 & 3 & 6 & 9 & 11 & 14 & 17 & 20 & 23 & 25 & 28 & 31 & 33 & 36 & 39 & 41 \\
\hline
\end{tabular}


TABLE A FOR DETERMINING ANGLE WITHIN STRIKING DISTANCE

FOR TREES WITHOUT A LEAN

TARGET WIDTH

\begin{tabular}{|c|c|c|c|c|c|c|c|c|c|c|c|c|c|c|c|}
\hline & 160 & 170 & 180 & 190 & 200 & 210 & 220 & 230 & 240 & 250 & 260 & 270 & 280 & 290 & 300 \\
\hline 1 & 179 & 179 & 179 & 179 & 179 & 179 & 179 & 179 & 179 & 179 & 179 & 179 & 179 & 179 & 179 \\
\hline 5 & 173 & 173 & 174 & 174 & 174 & 175 & 175 & 175 & 175 & 175 & 176 & 176 & 176 & 176 & 176 \\
\hline 10 & 166 & 167 & 167 & 168 & 169 & 169 & 170 & 170 & 170 & 171 & 171 & 172 & 172 & 172 & 172 \\
\hline 15 & 159 & 160 & 161 & 162 & 163 & 164 & 164 & 165 & 166 & 166 & 167 & 167 & 168 & 168 & 169 \\
\hline 20 & 152 & 154 & 155 & 156 & 157 & 158 & 159 & 160 & 161 & 162 & 163 & 163 & 164 & 164 & 165 \\
\hline 25 & 145 & 147 & 149 & 151 & 152 & 153 & 154 & 155 & 156 & 157 & 158 & 159 & 160 & 160 & 161 \\
\hline 30 & $\sqrt{39}$ & 141 & 143 & 145 & 147 & 148 & 149 & 151 & 152 & 153 & 154 & 155 & 156 & 157 & 157 \\
\hline 35 & 133 & 135 & 137 & 140 & 141 & 143 & 145 & 146 & 147 & 149 & 150 & 151 & 152 & 153 & 154 \\
\hline 40 & 127 & 130 & 132 & 134 & 136 & 138 & 440 & 142 & 743 & 145 & 146 & 147 & 148 & 149 & 150 \\
\hline 45 & 121 & 124 & 127 & 129 & 132 & 134 & 136 & 137 & 139 & 140 & 142 & 143 & 144 & L146 & 147 \\
\hline 50 & 116 & 119 & 122 & 124 & 127 & 129 & 131 & 133 & 135 & 136 & 138 & 139 & 141 & 142 & 143 \\
\hline 55 & 111 & 114 & 117 & 120 & 122 & 125 & 127 & 129 & 131 & 133 & 134 & 136 & 137 & 138 & 140 \\
\hline 60 & 106 & 110 & 113 & 115 & 118 & 121 & 123 & 125 & 127 & 129 & 130 & 132 & 134 & 135 & 136 \\
\hline 65 & 102 & 105 & 108 & 111 & 114 & 116 & 119 & 121 & 123 & 125 & 127 & 129 & 130 & 132 & 133 \\
\hline 70 & 98 & 101 & 104 & 107 & 110 & 113 & 115 & 117 & 119 & 122 & 123 & 125 & 127 & 128 & 130 \\
\hline 75 & 94 & 97 & 100 & 103 & 106 & 109 & 111 & 114 & 116 & 118 & 120 & 122 & 124 & 125 & 127 \\
\hline 80 & 90 & 93 & 97 & 100 & 103 & 105 & 108 & 110 & 113 & 115 & 117 & 119 & 121 & 122 & 124 \\
\hline 85 & 87 & 90 & 93 & 96 & 99 & 102 & 105 & 107 & 109 & 112 & 114 & 116 & 117 & 119 & 121 \\
\hline 90 & 83 & 87 & 90 & 93 & 96 & 99 & 101 & 104 & 106 & 108 & 111 & 113 & 115 & 116 & 118 \\
\hline 95 & 80 & 84 & 87 & 90 & 93 & 96 & 98 & 101 & 103 & 106 & 108 & 110 & 112 & 114 & 115 \\
\hline 100 & 77 & 81 & 84 & 87 & 90 & 93 & 95 & 98 & 100 & 103 & 105 & 107 & 109 & 111 & 113 \\
\hline 105 & 75 & 78 & 81 & 84 & 87 & 90 & 93 & 95 & 98 & 100 & 102 & 104 & 106 & 108 & 110 \\
\hline 110 & $\overline{72}$ & 75 & 79 & 82 & 85 & 87 & 90 & 93 & 95 & 97 & 100 & 102 & 104 & 106 & 107 \\
\hline 115 & 70 & 73 & 76 & 79 & 82 & 85 & 87 & 90 & 92 & 95 & 97 & 99 & 101 & 103 & 105 \\
\hline 120 & 67 & 71 & 74 & 77 & 80 & 82 & 85 & 88 & 90 & 92 & 95 & 97 & 99 & 101 & 103 \\
\hline 125 & 65 & 68 & 72 & 74 & 77 & 80 & 83 & 85 & 88 & 90 & 92 & 94 & 96 & 98 & 100 \\
\hline 130 & 63 & 66 & 69 & 72 & 75 & 78 & 80 & 83 & 85 & 88 & 90 & 92 & 94 & 96 & 98 \\
\hline 135 & 61 & 64 & 67 & 70 & 73 & 76 & 78 & 81 & 83 & 86 & 88 & 90 & 92 & 94 & 96 \\
\hline 140 & 59 & 63 & 65 & 68 & 71 & 74 & 76 & 79 & 81 & 84 & 86 & 88 & 90 & 92 & 94 \\
\hline 145 & 58 & 61 & 64 & 66 & 69 & 72 & 74 & 77 & 79 & 82 & 84 & 86 & 88 & 90 & 92 \\
\hline 150 & 56 & 59 & 62 & 65 & 67 & 70 & 73 & 75 & 77 & 80 & 82 & 84 & 86 & 88 & 90 \\
\hline 155 & 55 & 57 & 60 & 63 & 66 & 68 & 71 & 73 & 75 & 78 & 80 & 82 & 84 & 86 & 88 \\
\hline 160 & 53 & 56 & 59 & 61 & 64 & 67 & 69 & 71 & 74 & 76 & 78 & 80 & 82 & 84 & 86 \\
\hline 165 & 52 & 55 & 57 & 60 & 62 & 65 & 67 & 70 & 72 & 74 & 76 & 79 & 81 & 83 & 85 \\
\hline 170 & 50 & 53 & 56 & 58 & 61 & 63 & 66 & 68 & 70 & 73 & 75 & $\pi 7$ & 79 & 81 & 83 \\
\hline 175 & 49 & 52 & 54 & 57 & 59 & 62 & 64 & 67 & 69 & 71 & 73 & 75 & 77 & 79 & 81 \\
\hline 180 & 48 & 51 & 53 & 56 & 58 & 61 & 63 & 65 & 67 & 70 & 72 & 74 & 76 & 78 & 80 \\
\hline 185 & 47 & 49 & 52 & 54 & 57 & 59 & 61 & 64 & 66 & 68 & 70 & 72 & 74 & 76 & 78 \\
\hline 190 & 46 & 48 & 51 & 53 & 56 & 58 & 60 & 62 & 65 & 67 & 69 & 71 & 73 & 75 & 77 \\
\hline 195 & 45 & 47 & 50 & 52 & 54 & 57 & 59 & 61 & 63 & 65 & 67 & 69 & 71 & 73 & 75 \\
\hline 200 & 44 & 46 & 48 & 51 & 53 & 55 & 58 & 60 & 62 & 64 & 66 & 68 & 70 & 72 & 74 \\
\hline
\end{tabular}


TABLE A FOR DETERMINING ANGLE WITHIN STRIKING DISTANCE

FOR TREES WITHOUT A LEAN

TARGET WIDTH

\begin{tabular}{|c|c|c|c|c|c|c|c|c|c|c|c|c|c|c|c|}
\hline & 10 & 320 & 330 & 340 & 350 & 360 & 370 & 380 & 390 & 400 & 410 & 420 & 430 & 440 & 450 \\
\hline 1 & 179 & 179 & 179 & 179 & 179 & 179 & 179 & 179 & 118 & 179 & 179 & 179 & 179 & 79 & 等 \\
\hline 5 & 176 & 176 & 177 & 177 & 177 & 177 & 177 & 177 & 177 & 177 & 177 & 177 & 177 & 177 & 177 \\
\hline 10 & 173 & 173 & 173 & 173 & 173 & 174 & 174 & 174 & 174 & 174 & 174 & 175 & 175 & 175 & 175 \\
\hline 15 & 169 & 169 & 170 & 170 & 170 & 170 & 171 & 171 & 171 & 171 & 172 & 172 & 172 & 172 & 172 \\
\hline 20 & 165 & 166 & 166 & 167 & 167 & 167 & & 168 & 168 & 169 & 169 & 169 & 169 & 170 & 170 \\
\hline 25 & 162 & 162 & 163 & 163 & 164 & 164 & 165 & 165 & 165 & 166 & 166 & 166 & 167 & 167 & 167 \\
\hline 30 & 158 & 159 & 159 & 160 & 161 & 161 & 162 & 162 & 163 & 163 & 163 & & & & 165 \\
\hline 35 & 155 & 155 & 156 & 157 & 157 & 158 & 159 & 159 & 160 & 160 & 161 & 161 & 162 & 162 & 162 \\
\hline 40 & 151 & 152 & 153 & 154 & 154 & 155 & 156 & 156 & 157 & 157 & 158 & 158 & 159 & 159 & 160 \\
\hline 45 & 148 & 149 & 149 & 150 & 151 & 152 & 153 & 153 & 154 & 155 & 155 & & & & 157 \\
\hline 50 & 144 & 145 & 146 & 147 & 148 & 149 & 150 & 151 & 151 & 152 & 153 & 153 & 154 & 154 & 155 \\
\hline 55 & 141 & 142 & 143 & 144 & 145 & 146 & 147 & 148 & 148 & 149 & 150 & 151 & 151 & 152 & 153 \\
\hline 60 & 138 & 139 & 140 & 141 & 142 & 143 & 144 & 145 & 146 & 147 & 147 & 148 & 149 & 149 & 150 \\
\hline 65 & 134 & 136 & 137 & 138 & 139 & 140 & 141 & 142 & 743 & 144 & 145 & 146 & 146 & $7^{147}$ & 148 \\
\hline 70 & 131 & 133 & 134 & 135 & 136 & 13 & 139 & 140 & & 141 & & & & & 145 \\
\hline 75 & 128 & 130 & 131 & 132 & 134 & 135 & 136 & 137 & 13 & 139 & 140 & 141 & 142 & 142 & 143 \\
\hline 80 & 125 & 127 & 128 & 130 & 131 & 13 & 133 & 13 & & 136 & 137 & 138 & 39 & 140 & 141 \\
\hline 85 & 123 & 124 & 125 & & 12 & 12 & 131 & 13 & & 134 & 135 & 136 & 137 & 38 & 139 \\
\hline 90 & 120 & 121 & 123 & 124 & 126 & 12 & 12 & 12 & 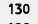 & 132 & 1 & 134 & & & 136 \\
\hline 95 & 117 & 119 & 120 & 122 & 123 & 12 & 12 & 12 & 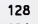 & 129 & 13 & & & & 134 \\
\hline 00 & 114 & 116 & 118 & 119 & 121 & 12 & 12 & 12 & 12 & 127 & 12 & 129 & 130 & 131 & 132 \\
\hline ع & 112 & 113 & 115 & 11 & 118 & 11 & 12 & 12 & 12 & 125 & 12 & . & 8 & & 130 \\
\hline 10 & 109 & 111 & 11 & & & & & & & 122 & 12 & 18 & 6 & 27 & 128 \\
\hline 15 & 107 & 109 & 110 & 112 & 11 & 11 & 116 & 11 & 11 & 120 & 12 & 3 & 4 & & 126 \\
\hline 20 & 105 & 106 & 108 & 110 & 111 & 11 & 11 & 11 & 11 & 118 & 1 & 121 & 122 & & 124 \\
\hline 25 & 102 & 104 & 106 & 107 & 109 & 11 & 112 & 11 & 11 & 116 & 11 & 118 & 120 & 121 & 122 \\
\hline 30 & 100 & 102 & 104 & 105 & 107 & 10 & 11 & 11 & 11 & 114 & 1 & . & & & 120 \\
\hline 35 & 98 & 100 & 101 & & 10 & 10 & 10 & 10 & 11 & 112 & 113 & 115 & 116 & 117 & 118 \\
\hline 40 & 96 & 98 & 99 & 101 & 103 & 10 & 10 & 10 & 10 & 110 & 11 & 113 & & & 116 \\
\hline 45 & 94 & 96 & 9 & 9 & 101 & 10 & 10 & & & & & & & & 114 \\
\hline 50 & 92 & 94 & 95 & 9 & 99 & 10 & 10 & 10 & 10 & 106 & 108 & 109 & 110 & 111 & 113 \\
\hline 55 & 90 & 92 & 94 & 95 & 9 & 9 & 10 & 10 & 10 & 104 & 10 & 107 & 108 & & 111 \\
\hline 160 & 88 & 90 & 92 & 93 & 95 & 97 & 98 & 10 & 101 & 103 & 104 & 105 & 107 & 108 & 109 \\
\hline 65 & 86 & 88 & 90 & 92 & 93 & 9 & 97 & 9 & 100 & 101 & 102 & 104 & 105 & 106 & 107 \\
\hline 170 & 85 & 87 & 88 & & 9 & 9 & 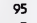 & & 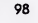 & 99 & 101 & & & 105 & 106 \\
\hline 175 & 83 & 85 & 87 & 88 & 90 & 92 & 93 & 95 & 96 & 98 & 99 & 100 & 102 & 103 & 104 \\
\hline 80 & 81 & 83 & 85 & 87 & 88 & 90 & 9 & 9 & 95 & 96 & 97 & 99 & 100 & 101 & 103 \\
\hline 85 & 80 & 82 & 83 & 85 & 87 & 88 & 90 & 92 & 93 & 94 & 96 & 97 & 99 & 100 & 101 \\
\hline 90 & 78 & 80 & 82 & 84 & 85 & 87 & 88 & 90 & 91 & 93 & 94 & 96 & 97 & 98 & 100 \\
\hline 80 & 77 & 79 & 80 & 82 & 84 & 85 & 87 & 89 & 90 & 91 & 93 & 94 & 96 & 97 & 98 \\
\hline S & 76 & 77 & 79 & 81 & 82 & 84 & 86 & 87 & 89 & 90 & 91 & 93 & 94 & 95 & 97 \\
\hline
\end{tabular}


TABLE A FOR DETERMINING ANGLE WITHIN STRIKING DISTANCE

FOR TREES HITHOUT A LEAN

TARGET WIDTH

\begin{tabular}{|c|c|c|c|c|c|c|c|c|c|c|c|c|c|c|c|}
\hline & 460 & 470 & 480 & 490 & 500 & 510 & 520 & 530 & 540 & 550 & 560 & 570 & 580 & 590 & 600 \\
\hline 1 & 180 & 180 & 180 & 180 & 180 & 180 & 180 & 180 & 180 & 180 & 180 & 180 & 180 & 180 & 180 \\
\hline 5 & 178 & 178 & 178 & 178 & 178 & 178 & 178 & 178 & 178 & 178 & 178 & 178 & 178 & 178 & 178 \\
\hline 10 & 175 & 175 & 175 & 175 & 175 & 176 & 176 & 176 & 176 & 176 & 176 & 176 & 176 & 176 & 176 \\
\hline 15 & 173 & 173 & 173 & 173 & 173 & 173 & 173 & 174 & 174 & 174 & 174 & 174 & 174 & 174 & 174 \\
\hline 20 & 170 & 170 & 170 & 171 & 171 & 171 & 171 & 171 & 172 & 172 & 172 & 172 & 172 & 172 & 172 \\
\hline 25 & 168 & 168 & 168 & 168 & 169 & 169 & 169 & 169 & 169 & 170 & 170 & 170 & 170 & 170 & 170 \\
\hline 30 & 165 & 165 & 166 & 166 & 166 & 167 & 167 & 167 & 167 & 168 & 168 & 168 & 168 & 168 & 169 \\
\hline 35 & 163 & 163 & 163 & 164 & 164 & 164 & 165 & 165 & 165 & 165 & 166 & 166 & 166 & 166 & 167 \\
\hline 40 & 160 & 161 & 161 & 161 & 162 & 162 & 163 & 163 & 163 & 163 & 164 & 164 & 164 & 165 & 165 \\
\hline 45 & 158 & 158 & 159 & 159 & 160 & 160 & 160 & 161 & 161 & 161 & 162 & 162 & 162 & 163 & 163 \\
\hline 50 & 155 & 156 & 156 & 157 & 157 & 158 & 158 & 159 & 159 & 159 & 160 & 160 & 160 & 161 & 161 \\
\hline 55 & 153 & 154 & 154 & 155 & 155 & 156 & 156 & 157 & 157 & 157 & 158 & 158 & 159 & 159 & 159 \\
\hline 60 & 151 & 151 & 152 & 152 & 153 & 154 & 154 & 154 & 155 & 155 & 156 & 156 & 157 & 157 & 157 \\
\hline 65 & 148 & 149 & 150 & 150 & 151 & 151 & 152 & 152 & 153 & 153 & 154 & 154 & 155 & 155 & 156 \\
\hline 70 & 146 & 147 & 147 & 148 & 149 & 149 & 150 & 150 & 151 & 151 & 152 & 152 & 153 & 153 & 154 \\
\hline 75 & 144 & T145 & 145 & 146 & $7^{147}$ & 147 & 148 & 148 & 149 & 149 & 150 & 151 & 151 & 151 & 152 \\
\hline 80 & 142 & 142 & 143 & 144 & 145 & 145 & 146 & 146 & 147 & 148 & 148 & 149 & 149 & 150 & 150 \\
\hline 85 & 139 & 140 & 141 & 142 & 142 & 143 & 144 & 144 & $\lfloor 145$ & 146 & 146 & 147 & 147 & 148 & 148 \\
\hline 90 & 137 & 138 & 139 & 140 & 140 & 141 & 142 & 142 & 143 & 144 & 144 & 145 & 146 & 146 & 147 \\
\hline 95 & 135 & 136 & 137 & 138 & 138 & 139 & 140 & 141 & 141 & 142 & 143 & 143 & 144 & 144 & 145 \\
\hline 100 & 133 & 134 & 135 & 136 & 136 & 137 & 138 & 139 & 139 & 140 & 141 & 141 & 142 & 143 & 743 \\
\hline 105 & 131 & 132 & 133 & 134 & 134 & 135 & 136 & 137 & 137 & 138 & 139 & 140 & 140 & 141 & 141 \\
\hline 110 & 129 & 130 & 131 & 132 & 133 & 133 & 134 & 135 & 136 & 136 & 137 & 138 & 138 & 139 & 140 \\
\hline 115 & 127 & 128 & 129 & 130 & 131 & 131 & 132 & 133 & 134 & 135 & 135 & 136 & 137 & 137 & 138 \\
\hline 120 & 125 & 126 & 127 & 128 & 129 & 130 & 130 & 131 & 132 & 133 & 134 & 134 & 135 & 136 & 136 \\
\hline 125 & 123 & 124 & 125 & 126 & 127 & 128 & 129 & 129 & 130 & 131 & 132 & 133 & 133 & 134 & 135 \\
\hline 130 & 121 & 122 & 123 & 124 & 125 & 126 & 127 & 128 & 129 & 129 & 130 & 131 & 132 & 132 & 133 \\
\hline 135 & 119 & 120 & 121 & 122 & 123 & 124 & 125 & 126 & 127 & 128 & 129 & 129 & 130 & 131 & 132 \\
\hline 140 & 117 & 118 & 119 & 121 & 122 & 122 & 123 & 124 & 125 & 126 & 127 & 128 & 128 & 129 & 130 \\
\hline 145 & 116 & 117 & 118 & 119 & 120 & 121 & 122 & 123 & 124 & 124 & 125 & 126 & 127 & 128 & 128 \\
\hline 150 & 114 & 115 & 116 & 117 & 118 & 119 & 120 & 121 & 122 & 123 & 124 & 124 & 125 & 126 & 127 \\
\hline 155 & 112 & 113 & 114 & 115 & 116 & 117 & 118 & 119 & 120 & 121 & 122 & 123 & 124 & 125 & 125 \\
\hline 160 & 110 & 112 & 113 & 114 & 115 & 116 & 117 & 118 & 119 & 120 & 121 & 121 & 122 & 123 & 124 \\
\hline 165 & 109 & 110 & 111 & 112 & 113 & 114 & 115 & 116 & 117 & 118 & 119 & 120 & 121 & 122 & 122 \\
\hline 170 & 107 & 108 & 109 & 110 & 112 & 113 & 114 & 115 & 116 & 117 & 117 & 118 & 119 & 120 & 121 \\
\hline 175 & 105 & 107 & 108 & 109 & 110 & 111 & 112 & 113 & 114 & 115 & 116 & 117 & 118 & 119 & 119 \\
\hline 180 & 104 & 105 & 106 & 107 & 108 & 110 & 111 & 112 & 113 & 114 & 115 & 115 & 116 & 117 & 118 \\
\hline 185 & 102 & 104 & 105 & 106 & 107 & 108 & 109 & 110 & 111 & 112 & 113 & 114 & 115 & 116 & 117 \\
\hline 190 & 101 & 102 & 103 & 104 & 106 & 107 & 108 & 109 & 110 & 111 & 112 & 113 & 114 & 114 & 115 \\
\hline 195 & 99 & 101 & 102 & 103 & 104 & 105 & 106 & 107 & 108 & 109 & 110 & 111 & 112 & 113 & 114 \\
\hline 200 & 98 & 99 & 100 & 102 & 103 & 104 & 105 & 106 & 107 & 108 & 109 & 110 & 111 & 112 & 113 \\
\hline
\end{tabular}


TABLE A FOR DETERMINING ANGLE WITHIN STRIKING DISTANCE

FOR TREES WITHOUT A LEAN

TARGET WIDTH

\begin{tabular}{|c|c|c|c|c|c|c|c|c|c|c|c|c|c|c|c|}
\hline & 610 & 620 & 630 & 640 & 650 & 660 & 670 & 680 & 690 & 700 & 710 & 720 & 730 & 740 & 750 \\
\hline 1 & 180 & 180 & 180 & 180 & 180 & 180 & 180 & 180 & 180 & 180 & 180 & 180 & 180 & 180 & \\
\hline 5 & 178 & 178 & 178 & 178 & 178 & 178 & 178 & 178 & 178 & 178 & 178 & 178 & 178 & 178 & 178 \\
\hline 10 & 176 & 176 & 176 & 176 & 176 & 177 & 177 & 177 & 177 & 177 & 177 & 177 & 177 & 177 & 177 \\
\hline 15 & 174 & 174 & 175 & 175 & 175 & 175 & 175 & 175 & 173 & 175 & 175 & 175 & 175 & 175 & 175 \\
\hline 20 & 172 & 173 & 173 & 173 & 173 & 173 & 173 & 173 & 173 & 173 & 174 & 174 & 174 & 174 & 174 \\
\hline 25 & 171 & 171 & 171 & 171 & 171 & 171 & 171 & 172 & 172 & 172 & 172 & 172 & 172 & 172 & 172 \\
\hline 30 & 169 & 169 & 169 & 169 & 169 & 170 & 170 & 170 & 170 & 170 & 170 & 170 & 171 & 171 & 171 \\
\hline 35 & 167 & 167 & 167 & 168 & 168 & 168 & 168 & 168 & 168 & 169 & 169 & 169 & 169 & 169 & 169 \\
\hline 40 & 165 & 165 & 166 & 166 & 166 & 166 & 166 & 167 & 167 & 167 & 167 & 167 & 167 & 168 & 168 \\
\hline 45 & 163 & 163 & 164 & 164 & 164 & 164 & 165 & 165 & 165 & 165 & 166 & 166 & 166 & 166 & 166 \\
\hline 50 & 161 & 162 & 162 & 162 & 163 & 163 & 163 & 163 & 164 & 164 & 164 & 164 & 164 & 165 & 165 \\
\hline 55 & 160 & 160 & 160 & 160 & 161 & 161 & 161 & 162 & 162 & 162 & 162 & 163 & 163 & 163 & 163 \\
\hline 60 & 158 & 158 & 158 & 159 & 159 & 159 & 160 & 160 & 160 & 161 & 161 & 161 & 161 & 162 & 162 \\
\hline 65 & 156 & 156 & 157 & 157 & 157 & 158 & 158 & 158 & 159 & 159 & 159 & 160 & 160 & 160 & 160 \\
\hline 70 & 154 & 155 & 155 & 155 & 156 & 156 & 156 & 157 & 157 & 157 & 158 & 158 & 158 & 159 & 159 \\
\hline 75 & 152 & 153 & 153 & 154 & 154 & 154 & 155 & 155 & 155 & 156 & 156 & 156 & 157 & 157 & 157 \\
\hline 80 & 151 & 151 & 151 & 152 & 152 & 153 & 153 & 154 & 154 & 154 & 155 & 155 & 155 & 156 & 156 \\
\hline 85 & 149 & 149 & 150 & 150 & 151 & 151 & 152 & 152 & 152 & 153 & 153 & 153 & 154 & 154 & 154 \\
\hline 90 & 147 & 148 & 148 & 149 & 149 & 149 & 150 & 150 & 151 & 151 & 152 & 152 & 152 & 153 & 153 \\
\hline 95 & 145 & 146 & 146 & 147 & 147 & 148 & 148 & 149 & 149 & 150 & 150 & 150 & 151 & 151 & 152 \\
\hline 100 & $\sqrt{44}$ & 744 & 145 & 145 & 146 & 146 & 147 & 147 & 148 & 148 & 149 & 149 & 149 & 150 & 150 \\
\hline 105 & 142 & 143 & 143 & 144 & 144 & 145 & 145 & 146 & 146 & 147 & 147 & 14 & 148 & 148 & 149 \\
\hline 10 & 140 & 141 & 142 & 142 & 143 & 143 & 144 & 744 & 145 & 145 & 146 & 146 & 146 & 147 & 147 \\
\hline 115 & 139 & 139 & 140 & 140 & 141 & 142 & 142 & 143 & 143 & 74 & 144 & 145 & 145 & 145 & 146 \\
\hline 120 & 137 & 138 & 138 & 139 & 139 & 140 & 141 & 141 & 142 & 142 & 143 & 143 & 144 & 144 & 145 \\
\hline 125 & 135 & 136 & 137 & 137 & 138 & 139 & 139 & 140 & 140 & 141 & 141 & 142 & 142 & 143 & 743 \\
\hline 13 & 134 & 134 & 13 & 136 & 136 & 137 & 138 & 138 & 139 & 139 & 140 & 140 & 141 & 141 & 142 \\
\hline 135 & 132 & 133 & 134 & 134 & 135 & 136 & 136 & 137 & 137 & 138 & 138 & 139 & 139 & 140 & 140 \\
\hline 140 & 131 & 131 & 132 & 133 & 133 & 134 & 135 & 135 & 13 & 136 & 137 & 13 & 13 & 139 & 139 \\
\hline 145 & 129 & 130 & 131 & 131 & 132 & 133 & 133 & 134 & 134 & 135 & 136 & 136 & 137 & 137 & 138 \\
\hline 150 & 128 & 128 & 125 & 130 & 130 & 131 & 132 & 132 & 133 & 134 & 134 & 135 & 135 & 136 & 136 \\
\hline 155 & 126 & 127 & 128 & 128 & 129 & 130 & 130 & 131 & 132 & 132 & 133 & 133 & 134 & 135 & 135 \\
\hline 160 & 125 & 125 & 126 & 127 & 128 & 128 & 129 & 130 & 130 & 131 & 131 & 132 & 133 & 133 & 134 \\
\hline 165 & 123 & 124 & 125 & 125 & 126 & 127 & 128 & 128 & 129 & 130 & 130 & 131 & 131 & 132 & 133 \\
\hline 170 & 122 & 123 & 123 & 124 & 125 & 125 & 126 & 127 & 128 & 128 & 129 & 129 & 130 & 131 & 131 \\
\hline 17 & 120 & 121 & 122 & 123 & 123 & 124 & 125 & 126 & 126 & 127 & 128 & 128 & 129 & 129 & 130 \\
\hline 180 & 119 & 120 & 121 & 121 & 122 & 123 & 124 & 124 & 125 & 126 & 126 & 127 & 127 & 128 & 129 \\
\hline 185 & 118 & 118 & 119 & 120 & 121 & 121 & 122 & 123 & 124 & 124 & 125 & 126 & 126 & 127 & 127 \\
\hline 190 & 116 & 117 & 118 & 119 & 119 & 120 & 121 & 122 & 122 & 123 & 124 & 124 & 125 & 126 & 126 \\
\hline 195 & 115 & 116 & 116 & 117 & 118 & 119 & 120 & 120 & 121 & 122 & 122 & 123 & 124 & 124 & 125 \\
\hline 200 & 113 & 114 & 115 & 116 & 117 & 118 & 118 & 119 & 120 & 121 & 121 & 122 & 123 & 123 & 12 \\
\hline
\end{tabular}


TABLE A FOR DETERMINING ANGLE WITHIN STRIKING DISTANCE

FOR TREES WITHOUT A LEAN

TARGET WIDTH

\begin{tabular}{|c|c|c|c|c|c|c|c|c|c|c|c|c|c|c|c|}
\hline & 760 & 770 & 780 & 790 & 800 & 810 & 820 & 830 & 840 & 850 & 860 & 870 & 880 & 890 & 900 \\
\hline 1 & 180 & 180 & 180 & 180 & 180 & 180 & 180 & 180 & 180 & 180 & 180 & 180 & 180 & 180 & 180 \\
\hline 5 & 178 & 179 & 179 & 179 & 179 & 179 & 179 & 179 & 179 & 179 & 179 & 179 & 179 & 179 & 179 \\
\hline 10 & 177 & 177 & 177 & 177 & 177 & 177 & 177 & 177 & 177 & 177 & 177 & 177 & 177 & 177 & 177 \\
\hline 15 & 175 & 176 & 176 & 176 & 176 & 176 & 176 & 176 & 176 & 176 & 176 & 176 & 176 & 176 & 176 \\
\hline 20 & 174 & 174 & 174 & 174 & 174 & 174 & 174 & 174 & 175 & 175 & 175 & 175 & 175 & 175 & 175 \\
\hline 25 & 172 & 173 & 173 & 173 & 173 & 173 & 173 & 173 & 173 & 173 & 173 & 173 & 173 & 174 & 174 \\
\hline 30 & 171 & 171 & 171 & 171 & 171 & 172 & 172 & 172 & 172 & 172 & 172 & 172 & 172 & 172 & 172 \\
\hline 35 & 169 & 170 & 170 & 170 & 170 & 170 & 170 & 170 & 170 & 171 & 171 & 171 & 171 & 171 & 171 \\
\hline 40 & 168 & 168 & 168 & 168 & 169 & 169 & 169 & 169 & 169 & 169 & 169 & 169 & 170 & 170 & 170 \\
\hline 45 & 166 & 167 & 167 & 167 & 167 & 167 & 167 & 168 & 168 & 168 & 168 & 168 & 168 & 168 & 169 \\
\hline 50 & 165 & 165 & 165 & 166 & 166 & 166 & 166 & 166 & 166 & 167 & 167 & 167 & 167 & 167 & 167 \\
\hline 55 & 164 & 164 & 164 & 164 & 164 & 165 & 165 & 165 & 165 & 165 & 165 & 166 & 166 & 166 & 166 \\
\hline 60 & 162 & 162 & 163 & 163 & 163 & 163 & 163 & 164 & 164 & 164 & 164 & 164 & 164 & 165 & 165 \\
\hline 65 & 161 & 161 & 161 & 161 & 162 & 162 & 162 & 162 & 162 & 163 & 163 & 163 & 163 & 163 & 164 \\
\hline 70 & 159 & 159 & 160 & 160 & 160 & 160 & 161 & 161 & 161 & 161 & 162 & 162 & 162 & 162 & 162 \\
\hline 75 & 158 & 158 & 158 & 158 & 159 & 159 & 159 & 160 & 160 & 160 & 160 & 160 & 161 & 161 & 161 \\
\hline 80 & 156 & 157 & 157 & 157 & 157 & 158 & 158 & 158 & 158 & 159 & 159 & 159 & 159 & 160 & 160 \\
\hline 85 & 155 & 155 & 155 & 156 & 156 & 156 & 157 & 157 & 157 & 157 & 158 & 158 & 158 & 158 & 159 \\
\hline 90 & 153 & 154 & 154 & 154 & 155 & 155 & 155 & 156 & 156 & 156 & 156 & 157 & 157 & 157 & 157 \\
\hline 95 & 152 & 152 & 153 & 153 & 153 & 154 & 154 & 154 & 155 & 155 & 155 & 155 & 156 & 156 & 156 \\
\hline 100 & 151 & 151 & 151 & 152 & 152 & 152 & 153 & 153 & 153 & 154 & 154 & 154 & 154 & 155 & 155 \\
\hline 105 & 149 & 149 & 150 & 150 & 151 & 151 & 151 & 152 & 152 & 152 & 153 & 153 & 153 & 153 & 154 \\
\hline 110 & 148 & 148 & 148 & 149 & 149 & 150 & 150 & 150 & 151 & 151 & 151 & 152 & 152 & 152 & 153 \\
\hline 115 & 146 & 147 & 147 & 148 & 148 & 148 & 149 & 149 & 149 & 150 & 150 & 150 & 151 & 151 & 151 \\
\hline 120 & 145 & 145 & 146 & 146 & 147 & 147 & 147 & 148 & 148 & 148 & 149 & 149 & 149 & 150 & 150 \\
\hline 125 & 144 & 744 & 144 & 145 & 145 & 146 & 146 & 146 & 147 & 147 & 148 & 148 & 148 & 149 & 149 \\
\hline 130 & 142 & 143 & 143 & 744 & 144 & 144 & 145 & 145 & 146 & 146 & 146 & 147 & 147 & 147 & 148 \\
\hline 135 & 141 & 141 & 142 & 142 & 143 & 143 & 144 & 144 & 144 & 145 & 145 & 146 & 146 & 146 & 147 \\
\hline 140 & 140 & 140 & 141 & 141 & 141 & 142 & 142 & 143 & 143 & 744 & 744 & 144 & 145 & 145 & 145 \\
\hline 145 & 138 & 139 & 139 & 140 & 140 & 141 & 141 & 141 & 142 & 142 & 143 & 143 & 144 & 144 & 744 \\
\hline 150 & 137 & 137 & 138 & 138 & 139 & 139 & 140 & 140 & 141 & 141 & 142 & 142 & 142 & 143 & 143 \\
\hline 155 & 136 & 136 & 137 & 137 & 138 & 138 & 139 & 139 & 139 & 140 & 140 & 141 & 141 & 142 & 142 \\
\hline 160 & 134 & 135 & 135 & 136 & 136 & 137 & 137 & 138 & 138 & 139 & 139 & 140 & 140 & 140 & 141 \\
\hline 165 & 133 & 134 & 134 & 135 & 135 & 136 & 136 & 137 & 137 & 138 & 138 & 138 & 139 & 139 & 140 \\
\hline 170 & 132 & 132 & 133 & 133 & 134 & 134 & 135 & 135 & 136 & 136 & 137 & 137 & 138 & 138 & 139 \\
\hline 175 & 131 & 131 & 132 & 132 & 133 & 133 & 134 & 134 & 135 & 135 & 136 & 136 & 137 & 137 & 137 \\
\hline 180 & 129 & 130 & 130 & 131 & 132 & 132 & 133 & 133 & 134 & 134 & 135 & 135 & 136 & 136 & 136 \\
\hline 185 & 128 & 129 & 129 & 130 & 130 & 131 & 131 & 132 & 132 & 133 & 133 & 134 & 134 & 135 & 135 \\
\hline 190 & 127 & 127 & 128 & 129 & 129 & 130 & 130 & 131 & 131 & 132 & 132 & 133 & 133 & 134 & 134 \\
\hline 195 & 126 & 126 & 127 & 127 & 128 & 129 & 129 & 130 & 130 & 131 & 131 & 132 & 132 & 133 & 133 \\
\hline 200 & 124 & 125 & 126 & 126 & 127 & 127 & 128 & 129 & 129 & 130 & 130 & 131 & 131 & 132 & 132 \\
\hline
\end{tabular}


TABLE A FOR DETERMINING ANGLE HITHIN STRIKING DISTANCE

FOR TREES WITHOUT A LEAN

TARGET WIDTH

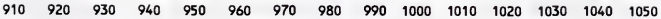

$\begin{array}{lllllllllllllllll}1 & 180 & 180 & 180 & 180 & 180 & 180 & 180 & 180 & 180 & 180 & 180 & 180 & 180 & 180 & 180\end{array}$

$\begin{array}{llllllllllllllll}5 & 179 & 179 & 179 & 179 & 179 & 179 & 179 & 179 & 179 & 179 & 179 & 179 & 179 & 179 & 179\end{array}$

$\begin{array}{llllllllllllllll}10 & 177 & 178 & 178 & 178 & 178 & 178 & 178 & 178 & 178 & 178 & 178 & 178 & 178 & 178 & 178\end{array}$

$\begin{array}{lllllllllllllllll}15 & 176 & 176 & 176 & 176 & 176 & 176 & 176 & 176 & 177 & 177 & 177 & 177 & 177 & 177 & 177\end{array}$

$\begin{array}{lllllllllllllllll}20 & 175 & 175 & 175 & 175 & 175 & 175 & 175 & 175 & 175 & 175 & 175 & 176 & 176 & 176 & 176\end{array}$

$\begin{array}{lllllllllllllllll}25 & 174 & 174 & 174 & 174 & 174 & 174 & 174 & 174 & 174 & 174 & 174 & 174 & 174 & 174 & 175\end{array}$

$\begin{array}{llllllllllllllll}30 & 172 & 173 & 173 & 173 & 173 & 173 & 173 & 173 & 173 & 173 & 173 & 173 & 173 & 173 & 173\end{array}$

$\begin{array}{llllllllllllllll}35 & 171 & 171 & 171 & 171 & 172 & 172 & 172 & 172 & 172 & 172 & 172 & 172 & 172 & 172 & 172\end{array}$

$\begin{array}{llllllllllllllll}40 & 170 & 170 & 170 & 170 & 170 & 170 & 171 & 171 & 171 & 171 & 171 & 171 & 171 & 171 & 171\end{array}$

$\begin{array}{llllllllllllllll}45 & 169 & 169 & 169 & 169 & 169 & 169 & 169 & 170 & 170 & 170 & 170 & 170 & 170 & 170 & 170\end{array}$

$\begin{array}{llllllllllllllll}50 & 167 & 168 & 168 & 168 & 168 & 168 & 168 & 168 & 168 & 169 & 169 & 169 & 169 & 169 & 169\end{array}$

$\begin{array}{lllllllllllllllll}55 & 166 & 166 & 167 & 167 & 167 & 167 & 167 & 167 & 167 & 167 & 168 & 168 & 168 & 168 & 168\end{array}$

$\begin{array}{lllllllllllllllll}D & 60 & 165 & 165 & 165 & 165 & 166 & 166 & 166 & 166 & 166 & 166 & 166 & 167 & 167 & 167 & 167\end{array}$

$\begin{array}{lllllllllllllllll}1 & 65 & 164 & 164 & 164 & 164 & 164 & 165 & 165 & 165 & 165 & 165 & 165 & 165 & 166 & 166 & 166\end{array}$

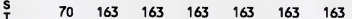

A 75

$\begin{array}{lllllll}75 & 161 & 161 & 162 & 162 & 162 & 162\end{array}$

$\begin{array}{lllllll}80 & 160 & 160 & 160 & 161 & 161 & 161\end{array}$

$\begin{array}{llllllllll}164 & 164 & 164 & 164 & 164 & 164 & 165 & 165 & 165\end{array}$

F 90

$\begin{array}{lllllll}85 & 159 & 159 & 159 & 159 & 160 & 160\end{array}$

$\begin{array}{llllllll}90 & 158 & 158 & 158 & 158 & 159 & 159\end{array}$

$\begin{array}{llllllll}95 & 156 & 157 & 157 & 157 & 157 & 158\end{array}$

$\begin{array}{lllllll}100 & 155 & 155 & 156 & 156 & 156 & 156\end{array}$

$\begin{array}{lllllll}105 & 154 & 154 & 155 & 155 & 155 & 155\end{array}$

$\begin{array}{lllllll}110 & 153 & 153 & 153 & 154 & 154 & 154\end{array}$

$\begin{array}{lllllll}115 & 152 & 152 & 152 & 153 & 153 & 153\end{array}$

$\begin{array}{lllllll}120 & 150 & 151 & 151 & 151 & 152 & 152\end{array}$

$\begin{array}{lllllll}125 & 149 & 150 & 150 & 150 & 151 & 151\end{array}$

$\begin{array}{lllllll}130 & 148 & 148 & 149 & 149 & 149 & 150 \\ 135 & 147 & 147 & 148 & 148 & 148 & 149\end{array}$

$\begin{array}{lllllll}140 & 146 & 146 & 146 & 147 & 147 & 147\end{array}$

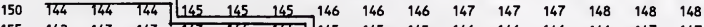

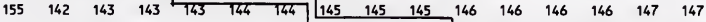

$\begin{array}{llllllllllllllllllllll}160 & 141 & 142 & 142 & 142 & 143 & 143 & 743 & 144 & 744 & 145 & 145 & 145 & 146 & 146\end{array}$

$\begin{array}{llllllllllllllllllll}165 & 140 & 141 & 141 & 141 & 142 & 142 & 142 & 143 & 143 & 143 & 144 & 144 & 1445\end{array}$

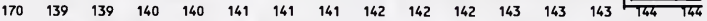

$\begin{array}{llllllllllllllll}175 & 138 & 138 & 139 & 139 & 140 & 140 & 140 & 141 & 141 & 141 & 142 & 142 & 142 & 143 & 143\end{array}$

$\begin{array}{llllllllllllllll}180 & 137 & 137 & 138 & 138 & 138 & 139 & 139 & 140 & 140 & 140 & 141 & 141 & 141 & 142 & 142\end{array}$

$\begin{array}{lllllllllllllllll}185 & 136 & 136 & 137 & 137 & 137 & 138 & 138 & 139 & 139 & 139 & 140 & 140 & 140 & 141 & 141\end{array}$

$\begin{array}{llllllllllllllll}190 & 135 & 135 & 136 & 136 & 136 & 137 & 137 & 138 & 138 & 138 & 139 & 139 & 139 & 140 & 140\end{array}$

$\begin{array}{lllllllllllllllll}195 & 134 & 134 & 134 & 135 & 135 & 136 & 136 & 137 & 137 & 137 & 138 & 138 & 139 & 139 & 139\end{array}$

$\begin{array}{llllllllllllllll}200 & 133 & 133 & 133 & 134 & 134 & 135 & 135 & 136 & 136 & 136 & 137 & 137 & 138 & 138 & 138\end{array}$ 
TARGET WIDTH

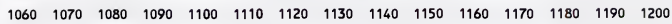

\begin{tabular}{|c|c|c|c|c|c|c|c|c|c|c|c|c|c|c|c|}
\hline 1 & 180 & 180 & 180 & 180 & 180 & 180 & 180 & 180 & 180 & 180 & 180 & 180 & 180 & 180 & 180 \\
\hline 5 & 179 & 179 & 179 & 179 & 179 & 179 & 179 & 179 & 179 & 179 & 179 & 179 & 179 & 179 & 179 \\
\hline 10 & 178 & 178 & 178 & 178 & 178 & 178 & 178 & 178 & 178 & 178 & 178 & 178 & 178 & 178 & 178 \\
\hline 15 & 177 & 177 & 177 & 177 & 177 & 177 & 177 & 177 & 177 & 177 & $1 \pi$ & 177 & 177 & 177 & 17 \\
\hline 20 & 176 & 176 & 176 & 176 & 176 & 176 & 176 & 176 & 176 & 176 & 176 & 176 & 176 & 176 & 176 \\
\hline 25 & 175 & 175 & 175 & 175 & 175 & 175 & 175 & 175 & 175 & 175 & 175 & 175 & 175 & 175 & 175 \\
\hline 30 & 174 & 174 & 174 & 174 & 174 & 174 & 174 & 174 & 174 & 174 & 174 & 174 & 174 & 174 & 174 \\
\hline 35 & 172 & 173 & 173 & 173 & 173 & 173 & 173 & 173 & 173 & 173 & 173 & 173 & 173 & 173 & 173 \\
\hline 40 & 171 & 171 & 172 & 172 & 172 & 172 & 172 & 172 & 172 & 172 & 172 & 172 & 172 & 172 & 172 \\
\hline 45 & 170 & 170 & 170 & 171 & 171 & 171 & 171 & 171 & 171 & 171 & 171 & 171 & 171 & 171 & 171 \\
\hline 50 & 169 & 169 & 169 & 170 & 170 & 170 & 170 & 170 & 170 & 170 & 170 & 0 & 170 & 170 & 170 \\
\hline 55 & 168 & 168 & 168 & 168 & 169 & 169 & 169 & 169 & 169 & 169 & 169 & 169 & 169 & 169 & 170 \\
\hline 60 & 167 & 167 & 167 & 167 & 168 & 168 & 168 & 168 & 168 & 168 & 168 & 168 & 168 & 168 & 169 \\
\hline 65 & 166 & 166 & 166 & 166 & 167 & 167 & 167 & 167 & 167 & 167 & 167 & 167 & 167 & 168 & 168 \\
\hline 70 & 165 & 165 & 165 & 165 & 165 & 166 & 166 & 166 & 166 & 166 & 166 & 166 & 166 & 167 & 167 \\
\hline 75 & 164 & 164 & 164 & 164 & 164 & 165 & 165 & 165 & 165 & 165 & 165 & 165 & 166 & 166 & 166 \\
\hline 80 & 163 & 163 & 163 & 163 & 163 & 164 & 164 & 164 & 164 & 164 & 164 & 164 & 165 & 165 & 165 \\
\hline 85 & 162 & 162 & 162 & 162 & 162 & 163 & 163 & 163 & 163 & 163 & 163 & 163 & 164 & 164 & 164 \\
\hline 90 & 161 & 161 & 161 & 16 & 161 & 162 & 162 & 162 & 162 & 162 & 162 & & & & 163 \\
\hline 95 & 160 & 160 & 160 & 160 & 160 & 161 & 161 & 161 & 161 & 161 & 161 & 162 & 162 & 162 & 162 \\
\hline 100 & 159 & 159 & 159 & 159 & 159 & 160 & 160 & 160 & 160 & 160 & 160 & 161 & 161 & 161 & 161 \\
\hline 05 & 158 & 158 & 158 & 158 & 158 & 159 & 159 & 159 & 159 & 159 & 159 & 160 & 160 & 160 & 160 \\
\hline 10 & 157 & 157 & 157 & 157 & 157 & 158 & 158 & 158 & 158 & 158 & 159 & 159 & 159 & 159 & 159 \\
\hline 115 & 156 & 156 & 156 & 156 & 156 & 157 & 157 & 157 & 157 & 157 & 158 & 158 & 158 & 158 & 158 \\
\hline 120 & 154 & 155 & 155 & 155 & 155 & 156 & 156 & 156 & 156 & 156 & 157 & & 157 & 157 & 157 \\
\hline 125 & 153 & 154 & 154 & 154 & 154 & 155 & 155 & 155 & 155 & 155 & 156 & 156 & 156 & 156 & 156 \\
\hline 130 & 152 & 153 & 153 & 153 & 153 & 154 & 154 & 154 & 154 & 155 & 155 & 155 & 155 & 155 & 156 \\
\hline 135 & 151 & 152 & 152 & 152 & 152 & 153 & 153 & 153 & 153 & 154 & 154 & & 1 & 154 & 155 \\
\hline 140 & 150 & 151 & 151 & 151 & 151 & 152 & 152 & 152 & 152 & 153 & 153 & 153 & 153 & 154 & 154 \\
\hline 145 & 149 & 150 & 150 & 150 & 150 & 151 & 151 & 151 & 151 & 152 & 152 & 152 & 152 & 153 & 153 \\
\hline 150 & 148 & 149 & 149 & 149 & 149 & 150 & 150 & 150 & 151 & 151 & 151 & 151 & 151 & 152 & 152 \\
\hline 155 & 147 & 148 & 148 & 148 & 149 & 149 & 149 & 149 & 150 & 150 & 150 & 150 & 151 & 151 & 151 \\
\hline 160 & 146 & 147 & 147 & 147 & 148 & 148 & 148 & 148 & 149 & 149 & 149 & 14 & 150 & 150 & 150 \\
\hline 165 & 145 & 146 & 146 & 146 & 147 & 147 & 147 & 147 & 148 & 148 & 148 & 148 & 149 & 149 & 149 \\
\hline 170 & $\sqrt{44}$ & 145 & 145 & 145 & 146 & 146 & 146 & 147 & 147 & 147 & 147 & 148 & 148 & 148 & 148 \\
\hline 175 & 143 & 144 & 144 & 144 & 145 & 145 & 145 & 146 & 146 & 146 & 146 & 147 & 147 & 147 & 147 \\
\hline 180 & 142 & 143 & 143 & 143 & 144 & 144 & 144 & 145 & 145 & 145 & $-^{146}$ & 146 & 146 & 146 & 147 \\
\hline 85 & 142 & 142 & 142 & 143 & 143 & 143 & 143 & 744 & 144 & 744 & 145 & 145 & 145 & 145 & 146 \\
\hline 190 & 141 & 141 & 141 & 142 & 142 & 142 & 143 & 143 & 143 & 143 & 144 & 144 & 744 & 145 & 145 \\
\hline 95 & 140 & 140 & 140 & 141 & 141 & 141 & 142 & 142 & 142 & 143 & 143 & 143 & 143 & 746 & $7 \overline{744}$ \\
\hline 00 & 139 & 139 & 139 & 140 & 140 & 140 & 141 & 141 & 141 & 142 & 142 & 142 & 143 & 143 & 143 \\
\hline
\end{tabular}


TABLE A FOR DETERMINING ANGLE HITHIN STRIKING DISTANCE

FOR TREES WITHOUT A LEAN

TARGET WIDTH

\begin{tabular}{|c|c|c|c|c|c|c|c|c|c|c|c|c|c|}
\hline 210 & 220 & 230 & 240 & 250 & 260 & 270 & 280 & 290 & 1300 & 1310 & 1320 & 1330 & 1340 \\
\hline 180 & 180 & 180 & 180 & 180 & 180 & 180 & 180 & 180 & 180 & 180 & $180^{\circ}$ & 180 & 180 \\
\hline 179 & 179 & 179 & 179 & 179 & 179 & 179 & 179 & 179 & 179 & 179 & 179 & 179 & 179 \\
\hline 178 & 178 & 178 & 178 & 178 & 178 & 178 & 178 & 178 & 178 & 178 & 178 & 178 & 178 \\
\hline 177 & 177 & 177 & 177 & 177 & 177 & 177 & 177 & 177 & 177 & 177 & 177 & 177 & 177 \\
\hline 176 & 176 & 176 & 176 & 176 & 176 & 176 & 176 & 176 & 176 & 177 & 177 & 177 & 177 \\
\hline 175 & 175 & 175 & 175 & 175 & 175 & 175 & 176 & 176 & 176 & 176 & 176 & 176 & 176 \\
\hline 174 & 174 & 174 & 174 & 175 & 175 & 175 & 175 & 175 & 175 & 175 & 175 & 175 & 175 \\
\hline 173 & 173 & 173 & 174 & 174 & 174 & 174 & 174 & 174 & 174 & 174 & 174 & 174 & 174 \\
\hline 172 & 172 & 173 & 173 & 173 & 173 & 173 & 173 & 173 & 173 & 173 & 173 & 173 & 173 \\
\hline 171 & 172 & 172 & 172 & 172 & 172 & 172 & 172 & 172 & 172 & 172 & 172 & 172 & 172 \\
\hline 171 & 171 & 171 & 171 & 171 & 171 & 171 & 171 & 171 & 171 & 171 & 171 & 171 & 171 \\
\hline 170 & 170 & 170 & 170 & 170 & 170 & 170 & 170 & 170 & 170 & 170 & 170 & 171 & 171 \\
\hline 169 & 169 & 169 & 169 & 169 & 169 & 169 & 169 & 169 & 169 & 170 & 170 & 170 & 170 \\
\hline 168 & 168 & 168 & 168 & 168 & 168 & 168 & 168 & 168 & 169 & 169 & 169 & 169 & 169 \\
\hline 167 & 167 & 167 & 167 & 167 & 167 & 167 & 168 & 168 & 168 & 168 & 168 & 168 & 168 \\
\hline 166 & 166 & 166 & 166 & 166 & 166 & 167 & 167 & 167 & 167 & 167 & 167 & 167 & 167 \\
\hline 165 & 165 & 165 & 165 & 165 & 166 & 166 & 166 & 166 & 166 & 166 & 166 & 166 & 166 \\
\hline 164 & 164 & 164 & 16 & 16 & 165 & 16 & 165 & 165 & 165 & 165 & 165 & 165 & 166 \\
\hline 163 & 163 & 163 & 163 & 164 & 164 & 164 & 164 & 164 & 164 & 164 & 164 & 165 & 165 \\
\hline 162 & 162 & 162 & 163 & 163 & 163 & 16 & 163 & 163 & 163 & & 164 & & \\
\hline 161 & 161 & 162 & 162 & 162 & 162 & 162 & 162 & 162 & 163 & 163 & 163 & 163 & 163 \\
\hline 160 & 160 & 161 & 161 & 161 & 161 & 161 & 161 & 162 & 162 & 162 & 162 & 162 & 162 \\
\hline 159 & 160 & 160 & 160 & 160 & 160 & 160 & 160 & 161 & 161 & 161 & 161 & 161 & 161 \\
\hline 158 & 159 & 159 & 159 & 159 & 159 & 15 & 160 & 160 & 160 & 160 & 160 & 160 & 161 \\
\hline 158 & 158 & 158 & 158 & 15 & 15 & & 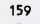 & 159 & 159 & 159 & 159 & 160 & 160 \\
\hline 157 & 157 & 157 & 157 & 157 & 158 & 158 & 158 & 158 & 158 & 158 & 159 & 159 & 159 \\
\hline 156 & 156 & 156 & 156 & 157 & 157 & 157 & 157 & 157 & 157 & & 158 & 158 & 158 \\
\hline 155 & 155 & 155 & 155 & 156 & 156 & 156 & 156 & 156 & 157 & 157 & 157 & 157 & 157 \\
\hline 154 & 154 & 154 & 155 & 155 & 155 & 15 & 155 & 156 & 156 & 156 & 156 & 156 & 156 \\
\hline 153 & 153 & 153 & 15 & 15 & 15 & 15 & 154 & 155 & 155 & 155 & 155 & 155 & 156 \\
\hline 152 & 152 & 153 & 153 & 153 & 153 & 153 & 154 & 154 & 154 & 154 & 154 & 155 & 155 \\
\hline 151 & 151 & 152 & 152 & 152 & 152 & 15 & 153 & 153 & 153 & 153 & 154 & 154 & 154 \\
\hline 150 & 151 & 151 & 151 & 151 & 151 & 152 & 152 & 152 & 152 & 153 & 153 & 153 & 153 \\
\hline 149 & 150 & 150 & 150 & 150 & 151 & 151 & 151 & 151 & 152 & 152 & 152 & 152 & 152 \\
\hline 149 & 149 & 149 & 149 & 150 & 150 & 150 & 150 & 150 & 151 & 151 & 151 & 151 & 152 \\
\hline 148 & 148 & 148 & 148 & 149 & 149 & 149 & 149 & 150 & 150 & 150 & 150 & 151 & 151 \\
\hline 147 & 147 & 147 & 148 & 148 & 148 & 148 & 149 & 149 & 149 & 149 & 149 & 150 & 150 \\
\hline 146 & 146 & 147 & 147 & 147 & 147 & 148 & 148 & 148 & 148 & 148 & 149 & 149 & 149 \\
\hline 145 & 145 & 146 & 146 & 146 & 146 & 147 & 147 & 147 & 147 & 148 & 148 & 148 & 148 \\
\hline 144 & 145 & 145 & 145 & 145 & 146 & 146 & 146 & 146 & 147 & 147 & 147 & 147 & 148 \\
\hline 143 & 144 & 744 & 744 & 145 & 145 & 145 & 145 & 146 & 146 & 146 & 146 & 147 & 147 \\
\hline
\end{tabular}


TABLE B FOR DETERMINING ANGLE WITHIN STRIKING DISTANCE

FOR TREES WITH A STRUCTURALLY DEFECTIVE LEAN

\section{TARGET WIDTH}

\begin{tabular}{|c|c|c|c|c|c|c|c|c|c|c|c|c|c|c|c|c|}
\hline & 1 & 10 & 20 & 30 & 40 & 50 & 60 & 70 & 80 & 90 & 100 & 110 & 120 & 130 & 140 & 150 \\
\hline 1 & 53 & 157 & 169 & 172 & 174 & 175 & 176 & 177 & 177 & 177 & 178 & 178 & 178 & 178 & 178 & 178 \\
\hline 5 & $\pi$ & 90 & 127 & 143 & 152 & 157 & 161 & 164 & 166 & 167 & 169 & 170 & 170 & 171 & 172 & 172 \\
\hline 10 & 6 & 53 & 90 & 113 & 127 & 136 & 143 & 148 & 152 & 155 & 157 & 159 & 161 & 163 & 164 & 165 \\
\hline 15 & 4 & 37 & 67 & 90 & 106 & 118 & 127 & 134 & 139 & 143 & 147 & 149 & 152 & 154 & 156 & 157 \\
\hline 20 & 3 & 28 & 53 & 74 & 90 & 103 & 113 & 121 & 127 & 132 & 136 & 140 & 143 & 146 & 148 & 150 \\
\hline 25 & 2 & 23 & 44 & 62 & 77 & 90 & 100 & 109 & 116 & 122 & 127 & 131 & 135 & 138 & 141 & 143 \\
\hline 30 & 2 & 19 & 37 & 53 & 67 & 80 & 90 & 99 & 106 & 113 & 118 & 123 & 127 & 130 & 134 & 136 \\
\hline 35 & 2 & 16 & 32 & 46 & 59 & 71 & 81 & 90 & 98 & 104 & 110 & 115 & 119 & 123 & 127 & 130 \\
\hline 40 & 1 & 14 & 28 & दा & 53 & 64 & 74 & 82 & 90 & 97 & 103 & 108 & 113 & 117 & 121 & 124 \\
\hline 45 & 1 & 13 & 25 & 37 & 48 & 58 & 67 & 76 & 83 & 90 & 96 & 101 & 106 & 111 & 115 & 118 \\
\hline 50 & 1 & 11 & 23 & 33 & 44 & 53 & 62 & 70 & 77 & 84 & 90 & 95 & 100 & 105 & 109 & 113 \\
\hline 55 & 1 & 10 & 21 & 31 & 40 & 49 & 57 & 65 & 72 & 79 & 85 & 90 & 95 & 100 & 104 & 107 \\
\hline 60 & 1 & 10 & 19 & 28 & 37 & 45 & 53 & 61 & 67 & 74 & 80 & 85 & 90 & 95 & 99 & 103 \\
\hline 65 & 1 & 9 & 17 & 26 & 34 & 42 & 50 & 57 & 63 & 69 & 75 & 80 & 85 & 90 & 94 & 98 \\
\hline 70 & 1 & 8 & 16 & 24 & 32 & 39 & 46 & 53 & 59 & 65 & 71 & 76 & 81 & 86 & 90 & 94 \\
\hline 75 & 1 & 8 & 15 & 23 & 30 & 37 & 44 & 50 & 56 & 62 & 67 & 73 & 77 & 82 & 86 & 90 \\
\hline 80 & 1 & 7 & 14 & 21 & 28 & 35 & 41 & 47 & 53 & 59 & 64 & 69 & 74 & 78 & 82 & 86 \\
\hline 85 & 1 & 7 & 13 & 20 & 26 & 33 & 39 & 45 & 50 & 56 & 61 & 66 & 70 & 75 & 79 & 83 \\
\hline 90 & 1 & 6 & 13 & 19 & 25 & 31 & 37 & 43 & 48 & 53 & 58 & 63 & 67 & 72 & 76 & 80 \\
\hline 95 & 1 & 6 & 12 & 18 & 24 & 29 & 35 & 40 & 46 & 51 & 56 & 60 & 65 & 69 & 73 & 77 \\
\hline 100 & 1 & 6 & 11 & 17 & 23 & 28 & 33 & 39 & 44 & 48 & 53 & 58 & 62 & 66 & 70 & 74 \\
\hline 105 & 1 & 5 & 11 & 16 & 22 & 27 & 32 & 37 & 42 & $\lcm{46}$ & 51 & 55 & 59 & 64 & 67 & 71 \\
\hline 110 & 1 & 5 & 10 & 16 & 21 & 26 & 31 & 35 & 40 & 44 & 49 & 53 & 57 & 61 & 65 & 69 \\
\hline 115 & 0 & 5 & 10 & 15 & 20 & 25 & 29 & 34 & 38 & 43 & 47 & 51 & 55 & 59 & 63 & 66 \\
\hline 120 & 0 & 5 & 10 & 14 & 19 & 24 & 28 & 33 & 37 & 41 & 45 & 49 & 53 & 57 & 61 & 64 \\
\hline 125 & 0 & 5 & 9 & 14 & 18 & 23 & 27 & 31 & 35 & 40 & 44 & 47 & 51 & 55 & 58 & 62 \\
\hline 130 & 0 & 4 & 9 & 13 & 17 & 22 & 26 & 30 & 34 & 38 & 42 & 46 & 50 & 53 & 57 & 60 \\
\hline 135 & 0 & 4 & 8 & 13 & 17 & 21 & 25 & 29 & 33 & 37 & 41 & 44 & 48 & 51 & 55 & 58 \\
\hline 140 & 0 & 4 & 8 & 12 & 16 & 20 & 24 & 28 & 32 & 36 & 39 & 43 & 46 & 50 & 53 & 56 \\
\hline 145 & 0 & 4 & 8 & 12 & 16 & 20 & 23 & 27 & 31 & 34 & 38 & 42 & 45 & 48 & 52 & 55 \\
\hline 150 & 0 & 4 & 8 & 11 & 15 & 19 & 23 & 26 & 30 & 33 & 37 & 40 & 44 & 47 & 50 & 53 \\
\hline 155 & 0 & 4 & 7 & 11 & 15 & 18 & 22 & 25 & 29 & 32 & 36 & 39 & 42 & 46 & 49 & 52 \\
\hline 160 & 0 & 4 & 7 & 11 & 14 & 18 & 21 & 25 & 28 & 31 & 35 & 38 & 41 & 44 & 47 & 50 \\
\hline 165 & 0 & 3 & 7 & 10 & 14 & 17 & 21 & 24 & 27 & 31 & 34 & 37 & 40 & 43 & 46 & 49 \\
\hline 170 & 0 & 3 & 7 & 10 & 13 & 17 & 20 & 23 & 26 & 30 & 33 & 36 & 39 & 42 & 45 & 48 \\
\hline 175 & 0 & 3 & 7 & 10 & 13 & 16 & 19 & 23 & 26 & 29 & 32 & 35 & 38 & 41 & 44 & 46 \\
\hline 180 & 0 & 3 & 6 & 10 & 13 & 16 & 19 & 22 & 25 & 28 & 31 & 34 & 37 & 40 & 43 & 45 \\
\hline 185 & 0 & 3 & 6 & 9 & 12 & 15 & 18 & 21 & 24 & 27 & 30 & 33 & 36 & 39 & 41 & 44 \\
\hline 190 & 0 & 3 & 6 & 9 & 12 & 15 & 18 & 21 & 24 & 27 & 29 & 32 & 35 & 38 & 40 & 43 \\
\hline 195 & 0 & 3 & 6 & 9 & 12 & 15 & 17 & 20 & 23 & 26 & 29 & 32 & 34 & 37 & 39 & 42 \\
\hline 200 & 0 & 3 & 6 & 9 & 11 & 14 & 17 & 20 & 23 & 25 & 28 & 31 & 33 & 36 & 39 & 41 \\
\hline
\end{tabular}


TABLE B FOR DETERMINING ANGLE HITHIN STRIKING DISTANCE

FOR TREES WITH A STRUCTURALLY DEFECTIVE LEAN

TARGET WIDTH

\begin{tabular}{|c|c|c|c|c|c|c|c|c|c|c|c|c|c|c|c|}
\hline & 160 & 170 & 180 & 190 & 200 & 210 & 220 & 230 & 240 & 250 & 260 & 270 & 280 & 290 & 300 \\
\hline 1 & 179 & 179 & 179 & 179 & 179 & 179 & 179 & 179 & 179 & 179 & 179 & 179 & 179 & 179 & 179 \\
\hline 5 & 173 & 173 & 174 & 174 & 174 & 175 & 175 & 175 & 175 & 175 & 176 & 176 & 176 & 176 & 176 \\
\hline 10 & 166 & 167 & 167 & 168 & 169 & 169 & 170 & 170 & 170 & 171 & 171 & 172 & 172 & 172 & 172 \\
\hline 15 & 159 & 160 & 161 & 162 & 163 & 164 & 164 & 165 & 166 & 166 & 167 & 167 & 168 & 168 & 169 \\
\hline 20 & 152 & 154 & 155 & 156 & 157 & 158 & 159 & 160 & 161 & 162 & 163 & 163 & 164 & 164 & 165 \\
\hline 25 & 145 & 147 & 149 & 151 & 152 & 153 & 154 & 155 & 156 & 157 & 158 & 159 & 160 & 160 & 161 \\
\hline 30 & 139 & 141 & 143 & 145 & 147 & 148 & 149 & 151 & 152 & 153 & 154 & 155 & 156 & 157 & 157 \\
\hline 35 & 133 & 135 & 137 & 140 & 141 & 143 & 145 & 146 & 147 & 149 & 150 & 151 & 152 & 153 & 154 \\
\hline 40 & 127 & 130 & 132 & 134 & 136 & 138 & 140 & 142 & 143 & 145 & 146 & 147 & 148 & 149 & 150 \\
\hline 45 & 121 & 124 & 127 & 129 & 132 & 134 & 136 & 137 & 139 & 140 & 142 & 143 & 144 & 146 & 147 \\
\hline 50 & 116 & 119 & 122 & 124 & 127 & 129 & 131 & 133 & 135 & 136 & 138 & 139 & 141 & 142 & 143 \\
\hline 55 & 111 & 114 & 117 & 120 & 122 & 125 & 127 & 129 & 131 & 133 & 134 & 136 & 137 & 138 & 140 \\
\hline 60 & 106 & 110 & 113 & 115 & 118 & 121 & 123 & 125 & 127 & 129 & 130 & 132 & 134 & 135 & 136 \\
\hline 65 & 102 & 105 & 108 & 111 & 114 & 116 & 119 & 121 & 123 & 125 & 127 & 129 & 130 & 132 & 133 \\
\hline 70 & 98 & 101 & 104 & 107 & 110 & 113 & 115 & 117 & 119 & 122 & 123 & 125 & 127 & 128 & 130 \\
\hline 73 & 94 & 97 & 100 & 103 & 106 & 109 & 111 & 114 & 116 & 118 & 120 & 122 & 124 & 125 & 127 \\
\hline 80 & 90 & 93 & 97 & 100 & 103 & 105 & 108 & 110 & 113 & 115 & 117 & 119 & 121 & 122 & 124 \\
\hline 85 & 87 & 90 & 93 & 96 & 99 & 102 & 105 & 107 & 109 & 112 & 114 & 116 & 117 & 119 & 121 \\
\hline 90 & 83 & 87 & 90 & 93 & 96 & 99 & 101 & 104 & 106 & 108 & 111 & 113 & 115 & 116 & 118 \\
\hline 95 & 80 & 84 & 87 & 90 & 93 & 96 & 98 & 101 & 103 & 106 & 108 & 110 & 112 & 114 & 115 \\
\hline 100 & 77 & 81 & 84 & 87 & 90 & 93 & 95 & 98 & 100 & 103 & 105 & 107 & 109 & 111 & 113 \\
\hline 105 & 75 & 78 & 81 & 84 & 87 & 90 & 93 & 95 & 98 & 100 & 102 & 104 & 106 & 108 & 110 \\
\hline 110 & 72 & 75 & 79 & 82 & 85 & 87 & 90 & 93 & 95 & 91 & 100 & 102 & 104 & 106 & 107 \\
\hline 115 & 70 & 73 & 76 & 79 & 82 & 85 & 87 & 90 & 92 & 95 & 97 & 99 & 101 & 103 & 105 \\
\hline 120 & 67 & 71 & 74 & 77 & 80 & 82 & 85 & 88 & 90 & 92 & 95 & 97 & 99 & 101 & 103 \\
\hline 125 & 65 & 68 & 72 & 74 & 77 & 80 & 83 & 85 & 88 & 90 & 92 & 94 & 96 & 98 & 100 \\
\hline 130 & 63 & 66 & 69 & 72 & 75 & 78 & 80 & 83 & 85 & 88 & 90 & 92 & 94 & 96 & 98 \\
\hline 135 & 61 & 64 & 67 & 70 & 73 & 76 & 78 & 81 & 83 & 86 & 88 & 90 & 92 & 94 & 96 \\
\hline 140 & 59 & 63 & 65 & 68 & 71 & 74 & 76 & 79 & 81 & 84 & 86 & 88 & 90 & 92 & 94 \\
\hline 145 & 58 & 61 & 64 & 66 & 69 & 72 & 74 & 77 & 79 & 82 & 84 & 86 & 88 & 90 & 92 \\
\hline 150 & 56 & 59 & 62 & 65 & 67 & 70 & 73 & 75 & 77 & 80 & 82 & 84 & 86 & 88 & 90 \\
\hline 155 & 55 & 57 & 60 & 63 & 66 & 68 & 71 & 73 & 75 & 78 & 80 & 82 & 84 & 86 & 88 \\
\hline 160 & 53 & 56 & 59 & 61 & 64 & 67 & 69 & 71 & 74 & 76 & 78 & 80 & 82 & 84 & 86 \\
\hline 165 & 52 & 55 & 57 & 60 & 62 & 65 & 67 & 70 & 72 & 74 & 76 & 79 & 81 & 83 & 85 \\
\hline 170 & 50 & 53 & 56 & 58 & 61 & 63 & 66 & 68 & 70 & 73 & 75 & 77 & 79 & 81 & 83 \\
\hline 175 & 49 & 52 & 54 & 57 & 59 & 62 & 64 & 67 & 69 & 71 & 73 & 75 & 77 & 79 & 81 \\
\hline 180 & 48 & 51 & 53 & 56 & 58 & 61 & 63 & 65 & 67 & 70 & 72 & 74 & 76 & 78 & 80 \\
\hline 185 & 47 & 49 & 52 & 54 & 57 & 59 & 61 & 64 & 66 & 68 & 70 & 72 & 74 & 76 & 78 \\
\hline 190 & 46 & 48 & 51 & 53 & 56 & 58 & 60 & 62 & 65 & 67 & 69 & 71 & 73 & 75 & 77 \\
\hline 195 & 45 & 47 & 50 & 52 & 54 & 57 & 59 & 61 & 63 & 65 & 67 & 69 & 71 & 73 & 75 \\
\hline 200 & 44 & 46 & 48 & 51 & 53 & 55 & 58 & 60 & 62 & 64 & 66 & 68 & 70 & 72 & 74 \\
\hline
\end{tabular}


APPENDIX E: HAZARD TREE RECORD FORMS 
-

3

○

-

0

0

-

-

.

$0^{\circ}$ 
SHEET

OF

HAZARD TREE SURVEILLACE RECORD

DISTRICT: SITE :

INSPECTOR:

DATE :

\begin{tabular}{|c|c|c|c|c|c|c|c|}
\hline \begin{tabular}{c|} 
TREE \\
$\#$
\end{tabular} & SPECIES & DBH & HT & LOCATION OF TREE & $\begin{array}{l}\text { DESCRIPTION } \\
\text { OF DEFECT }\end{array}$ & $\begin{array}{l}\text { DESCRIPTION } \\
\text { OF TARGET }\end{array}$ & $\begin{array}{l}\text { ACTION } \\
\text { RECOMMENDED }\end{array}$ \\
\hline & & & & & & & \\
\hline & & & & & & & \\
\hline & & & & & & & \\
\hline & & & & & & & \\
\hline & & & & & & & 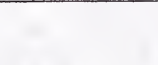 \\
\hline & & & & & & & \\
\hline & & & & & & & \\
\hline & & & & & & & \\
\hline & & & & & & & \\
\hline & & & & & & & \\
\hline & & & & & & & \\
\hline & & & & & & & \\
\hline
\end{tabular}


0 
HAZARD TREE EXAMINATION RECORD

DISTRICT : SITE:

INSPECTOR:

DATE :

\begin{tabular}{|c|c|c|c|c|c|c|c|c|c|c|}
\hline$\underset{\#}{\operatorname{TREE}}$ & SPECIES & DBH & HT & $\begin{array}{l}\text { PESCRIPTION } \\
\text { OF DEFECT }\end{array}$ & $\begin{array}{l}\text { TREE } \\
\text { FAILURE } \\
\text { RATING }\end{array}$ & $\begin{array}{l}\text { TARGET } \\
\text { IMPACT } \\
\text { RATING }\end{array}$ & $\begin{array}{l}\text { HAZARD } \\
\text { RATING }\end{array}$ & $\begin{array}{l}\text { ACTION } \\
\text { RECOMMENDED }\end{array}$ & $\frac{\text { ACTION }}{\text { DATE }}$ & $\begin{array}{l}\text { COMPLETED } \\
\text { INITIALS }\end{array}$ \\
\hline & & & & & & & & & & \\
\hline & & & & & & & & & & \\
\hline & & & & & & & & & & \\
\hline & & & & & & & & & & \\
\hline & & & & & & & & & & \\
\hline & & & & & & & & & & \\
\hline & & & & & & & & & & \\
\hline & & & & & & & & & & \\
\hline & & & & & & & & & & \\
\hline
\end{tabular}


$O_{0}$

6 


\section{CASE INCIDENT RECORD}

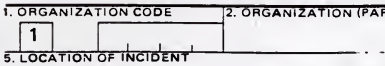

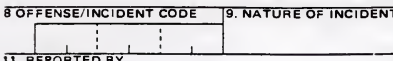

11. REPORTED BY
14. RECEIVED BY

8. INVESTIGATED BY

\begin{tabular}{|c|c|c|c|c|c|c|c|}
\hline & INVOLVED PERSONS & AD. ADRESS & 24. PHONE & $\begin{array}{r}25 . \\
\text { SEX }\end{array}$ & $\begin{array}{c}26 . \\
\text { RACE }\end{array}$ & $\begin{array}{l}27 . \\
\text { AGE }\end{array}$ & $\begin{array}{l}\text { 2B. DATE OF } \\
\text { BIRTH }\end{array}$ \\
\hline 1 & & & & & & & \\
\hline 2 & & & & & & & \\
\hline 3 & & & & & & & \\
\hline 4 & & & & & & & \\
\hline
\end{tabular}

\begin{tabular}{|c|c|c|c|c|c|c|c|}
\hline \multirow{2}{*}{$\mid \begin{array}{l}\text { O. W' } \overline{\text { WIEN }} \\
\text { DID IT } \\
\text { OCCUR? }\end{array}$} & мо. & DAY & YA. & \multirow{2}{*}{$\begin{array}{l}24 \\
\text { HOUR } \\
\text { TIME }\end{array}$} & HRS. & MIN. & \multirow{2}{*}{$\begin{array}{c}\text { 7. DAY } \\
\text { OF } \\
\text { WEEK }\end{array}$} \\
\hline & ; & : & : & & ! & $\vdots$ & \\
\hline
\end{tabular}
10. HOW REPORTED 19. OFFICER/AANGEA NO.

20. WHEN CLEARED

TIME DISPOSITION

21. PHONE $\begin{aligned} & \text { HOME } \\ & \text { BUSINESS }\end{aligned}$ 17. WHEN INVESTEATED DATE 29. DETAILS OF INCIDENT

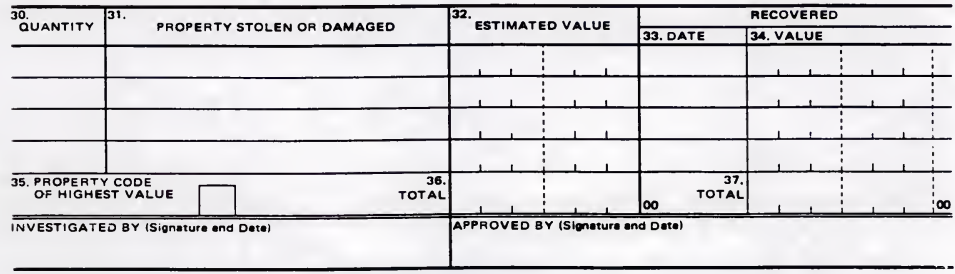


-

○

-

0

-

-

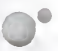

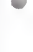


Qu S. GOVERNMENT PAINTING OFFICE 1978-722-513

FORM NO, 10-344

(Rev. 3-73)

\begin{tabular}{l} 
NATIONAL PARK SERVICE \\
SUPPLEMENTARY CASE/INCIDENT RECORD \\
\hline ORGANIZATION (PARK) NAME
\end{tabular}

NATURE OF INCIDENT
U.S. DEPARTMENT OF THE INTERIOR

NATIONAL PARK SERVICE

CASE/INCIDENT

NUMBER

DATE OF INCIDENT

COMPLAINANTS NAME

COMPLAINANTS ADDRESS

RESULTS OF INVESTIGATION 
-

.

0

-

○

-

$0^{\circ}$

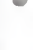


REPORT OF TREE FAILURE (1)

(Mechanical break, collapse, or uprooting)

REPORTING AGENCY:

(A) Tree and stand

Species:

Approximate dbh of tree: inches

Approximate age of tree: years

Forest type:

Stand age class:

$$
\text { Overmature }
$$

_ Mature

Young-growth

Elevation of site: All-age

(B) Class of mechanical failure

Upper bole (top half)
Lower bole
Butt (lower 6 feet)
Limb
Root, including uprooting

(C) Tree defect or fault leading to failure (2)

Rot (trunk, limb, or root)

Sweep

Tree dead - snag

Fire wound

Leaning

Lightning wound

Mechanical wound

Cracks or splits

Fork or multiple top

Twin bole or basal fork

Dead top or branch

Widow-maker or hang-up

Canker, rust

Canker, mistletoe

Other:

Unknown or none

(D) Contributing factors

Wind
- Snow
- Erosion
- Soil - saturation

Stream bank erosion
Shallow rooting
Tree striking tree
Other:
Unknown or none

UNIT:

(E) Time and location of incident

Approximate hour:

Month, year:

County:

State:

Site open for public use: Yes No

(F) Land ownership

_ Federal

State

_ Other public:

_ Private

_ Public utility

(G) Site category

Established camp or picnic ground

Other established public use site (3)

Volunteer site (4)

Marked trail

Special use site (5)

Roadside

_ Residence site (5)

Other: 8

Urban

(H) Property or person directly affected

- Agency

Recreationist

_ Forest industry

_. Permittee-Concessionaire

Other:

Contractor

_ Public utility

(I) Consequences

Clean-up work required

_ Property damaged:

Property loss estimate:S

Injuries

(Do not give tree values)

Medical attention required

Fatalities

(J) Name of site: (8)

Comments:

Only failures of a size capable of inflicting some damage or injury should be reported. Minor limb failures should not be reported unless they were potentially dangerous. Do not report simple death of a tree or part of a tree unless it resulted in mechanical failure. Trees removed prior to failure should not be reported. 


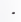

○

?

0

.

-

$0^{\circ}$

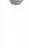


Alder (Alder incana, A. sinuata)

Principal hazards: Root loosening by water (Wagener, 1963).

Quaking Aspen (Populus tremuloides)

Principal hazards: Killed trees or tops (Wagener, 1963). Sporophores usually indicate decay that extends 5- 6 feet above and below the conk. Aspen, because of their fragile bark, are especially susceptible to trunk injuries. Trees in developed recreation sites are often injured by visitors; such injuries often lead to infection by canker producing fungi. Cankers do not weaken trees structurally unless they are large or are infected by decay fungi. Increment cores may be necessary to define the amount of defect. However, cores should be taken only when necessary, as they produce wounds which may provide infection sites for canker and decay fungi. Also, cores taken from trees with internal decay provide new points from which existing decay can move into unaffected tissues formed since the decay process was initiated in the tree. (Johnson, 1981)

Black Cottonwood (Populus trichocarpa)

Principal hazards: Cankers, heart and sap rots, undermined roots.

The wood of cottonwoods is soft and quite brash, as well as having little resistance to decay. Cottonwoods are also subject to several bark canker diseases that may be followed by decay. On this account they should be inspected at least annually for defects that could lead to breakage. Prompt action should be taken to remedy any potentially hazardous conditions found. Near streams the undermining of root systems during high water should be watched. (Wagener, 1963) The main defect of cottonwood is large dead or rotten branches. Large trees are sometimes rotten and the amount of sound wood should be measured on increment cores. Slime flux (foul-smelling and unsightly bleeding from wounds) and wetwood should not be confused with woodrotting fungi.

These indicators are common in hardwoods and usually do not indicate decay. Many river bottom trees are not windfirm because of the high water table and coarse soil structure. (Johnson, 1981)

Rocky Mountain Maple (Acer glabrum)

Birch (Betula glandulosa, B. occidentalis, B. papyrifera)

Pines (Pinus sp.)

Principal hazards: High horizontal cankers, heart rot from fire wounds, large low-crotched forks. Damage to life and property from pines,..., has occurred almost exclusively during severe storms. These storms have 
been intense enough to cause the breakage of much sound wood or the uprooting of trees with relatively sound root systems. The sapwood of most California pines is quite thick in proportion to the total cross section, and the heartwood tends to be relatively sound except from occasional old, overmature specimens. In these trees the rot is usually in association with old fire wounds. On the other hand the wood is mechanically not as strong as in some other conifers, such as Douglas-fir. Consequently the wood of pines may break under the stress of exceptionally high winds, whereas species with tougher wood can be expected to remain intact when under the same stresses.

Any trunk abnormality that tends to seriously disrupt the normal round form at some particular point is likely to increase the possibility of breakage there. Thus, in at least one district in California, deep, horizontal cankers at some distance from the ground have resulted in an occasional breaking over of the cankered trunks at the canker during severe storms. On the other hand breakage has not been noted from cankers of the same type located within a few feet of the ground. The wood around these cankers (which are probably caused by a tree rust) is hard and tough. Only when the canker depressions become deep and occur 16 or more feet from the ground do they seem to weaken the trunk of the affected tree enough to cause breakage in occasional cases during severe windstorms. In a few cases large forks in pines have broken out during heavy winds,... However, this does not mean that all forked pines should be considered hazardous. (Wagener, 1963) Dwarf mistletoe is the major disease of pines in the Rocky Mountains. Large witches'-brooms should be removed to eliminate this hazard and improve tree vigor. Wood-rotting fungi are common in pines. Indicators of rot include basal fire scars, unusual swellings, swollen or punky knots, and sporophores. However, because of the dry climate in this Region, most wood-rotting fungi rarely form easily visible sporophores. Burls and cankers commonly occur on pines, but do not constitute a hazard unless they are so extensive as to weaken stem structure or are complicated by rot. Increment cores should be taken to determine the amount of sound wood in trees exhibiting signs of decay. (Johnson, 1981)

Lodgepole Pine (Pinus contorta) Lodgepole pine has thin bark which is easily damaged resulting in increased susceptibility to decay (Johnson, 1981).

Ponderosa Pine (Pinus ponderosa)

Western White Pine (Pinus monticola) 
Limber Pine (Pinus flexilis)

Whitebark Pine (Pinus albicaulis)

Larch (Larix occidentalis, L. lyalli)

Fir (Abies lasiocarpa, A. grandis)

Rot commonly occurs in overmature spruce and true fir.

Subalpine fir is particularly susceptible to decay fungi and the frequency and extent of rot increases markedly with age. Trunk wounds, punky knots, frost cracks, and broken tops often indicate decay in spruce and fir; whereas, burls and cankers do not. Sporophores, when present, indicate advanced decay. When a defect is suspected, increment cores should be taken to confirm the presence of rot. Spruce and fir usually are not windfirm because of shallow root systems. Therefore any damage to the roots will increase the probability of windthrow. Rust brooms, unless large, are not a serious hazard. Both spruce and true fir are relatively tolerant of trunk damage, but once damage occurs they are very susceptible to decay. (Johnson, 1981)

Engelmann Spruce (Picea engelmanni)

See Johnson's (1981) remarks for fir above.

Douglas Fir (Pseudotsuga menziesii)

Western Hemlock (Tsuga heterophylla) 
0

0

○

-

-

0

.

-

$0^{\circ}$

\section{.}




\section{APRENDIX G}

\section{LITERATURE CITED}

Hagle, Susan K., Scott Tunnock, Kenneth E. Gibson, Carma J. Gilligan. 1987. Field guide to diseases and insect pests of Idaho and Montana forests. USDA For. Ser. Nor. Reg., Missoula, Montana.

Hamilton, Jr. David A. and Bruce M. Edwards. 1976. Modeling the probability of individual tree mortality. USDA For. Ser. Res. Paper INT-185.

Johnson, David w. 1981. Tree hazards; recognition and reduction in recreation sites. USDA For Ser. Tech. Rep. R2-1.

Larson, Rolf L. 1984. Report on hazard tree identification in Glacier National Park, Montana. Unpublished Report. Glacier National Park.

McArthur, Katherine L. 1977. Survey of fallen trees in headquarters area. Unpublished Report. Glacier National Park.

USDI. 1991. Natural Resources Management Guideline. NPS-77.

Wallis, G.W., D.J. Morrison, and D.W. Ross. 1980. Tree hazards in recreation sites in British Columbia. British Columbia Ministry of Lands, Parks and Housing and Canadian Forestry Service Joint Report No. 13.

Wagener, willis. 1963. Judging hazard from native trees in California recreational areas: a guide for professional

foresters. USDA For. Ser. Res. Paper PSW-P1.

\section{ADDITIONAL READING}

Schmierer, Alan. 1992. DRAFT Western Region directive on the management of vegetation hazards. National park Service, Western Region, San Francisco, California.

USDA, Forest Service and Idaho Department of State Lands. Forest insect and disease identification and management. USDA, Forest Service, Northern Region. Missoula, Montana. 
0

0

-

0

-

0

0

- 

